Summary of the
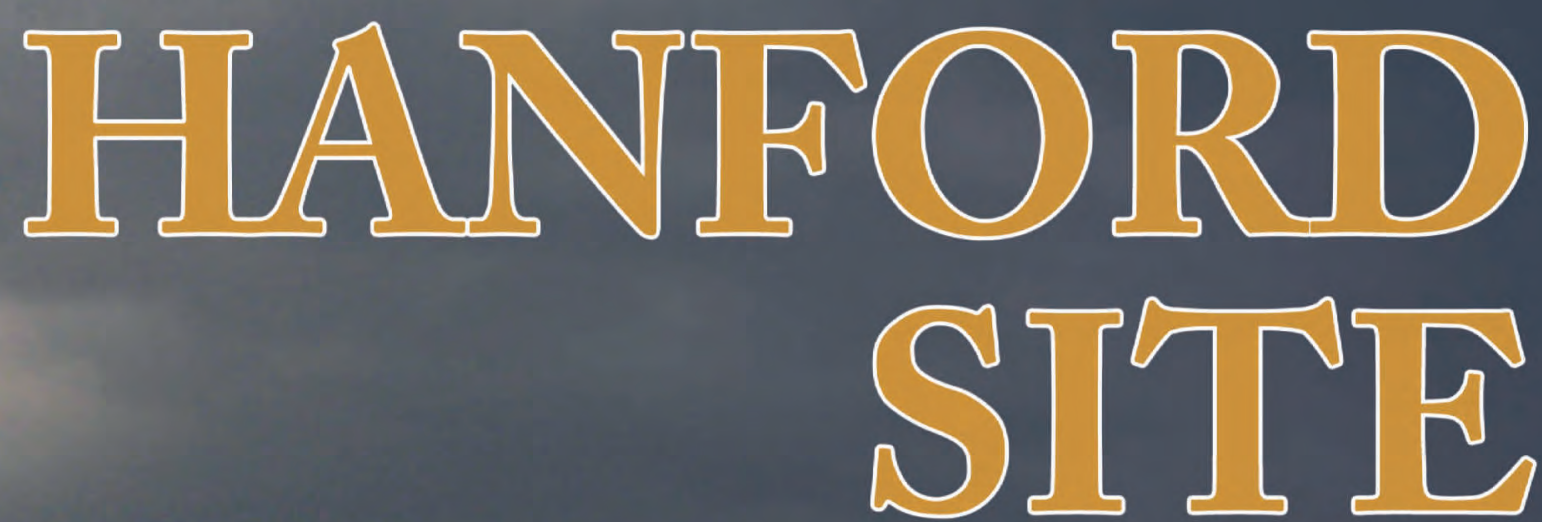

\title{
ENVIRONMENTAL REPORT
}

for Calendar Year 2007 


\section{Summary of the}
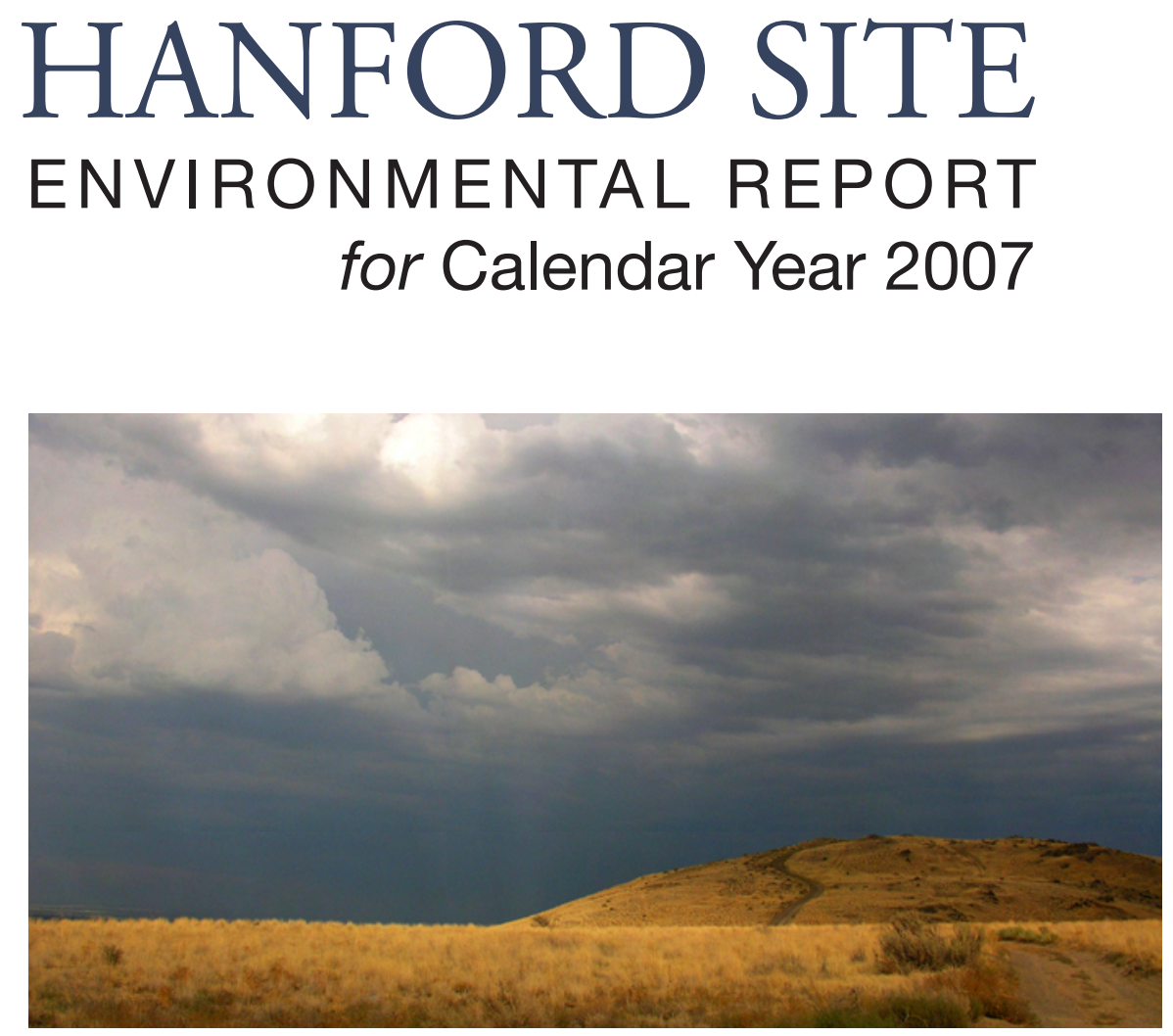

\section{EDITORS}

J.P. DUNCAN

T.M. POSTON

\section{R.L. DIRKES}

\section{SEPTEMBER 2008}

Prepared for the U.S. Department of Energy by Pacific Northwest National Laboratory under contract DE-AC05-76RL01830, with contributions from Bechtel National, Inc.; CH2M HILL Hanford Group, Inc.; Fluor Hanford, Inc. and its subcontractors; and Washington Closure Hanford LLC.

Pacific Northwest National Laboratory Richland, Washington 


\section{DISCLAIMER}

This report was prepared as an account of work sponsored by an agency of the United States Government. Reference herein to any specific commercial product, process, or service by trade name, trademark, manufacturer, or otherwise does not necessarily constitute or imply its endorsement, recommendation, or favoring by the United States Government or any agency thereof, or Battelle Memorial Institute.

\section{COVER}

The cover photo shows a late summer weather system passing over a shrubsteppe ecosystem that surrounds the Hanford Site. The photo was taken by AE Rakowski, Pacific Northwest National Laboratory, Richland, Washington. The cover and layout designs are by SB Colson and document layout was done by KR Neiderhiser, both of Pacific Northwest National Laboratory, Richland, Washington.

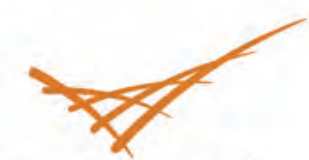

\section{Pacific Northwest}




\section{CONTENTS}

Introduction 1

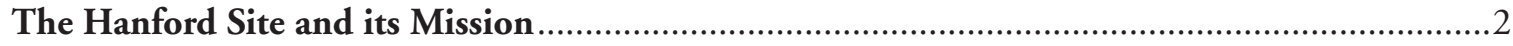

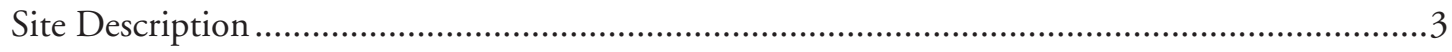

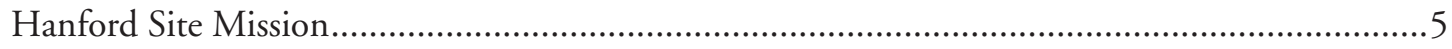

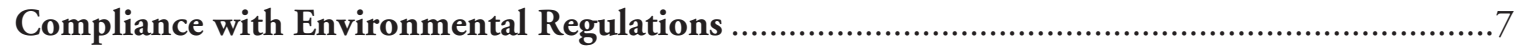

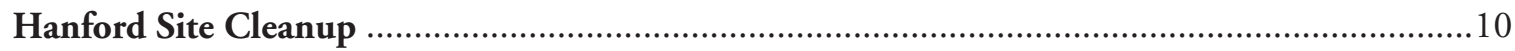

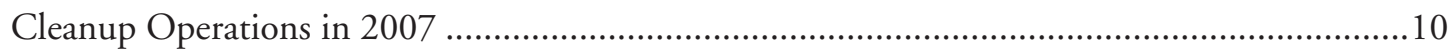

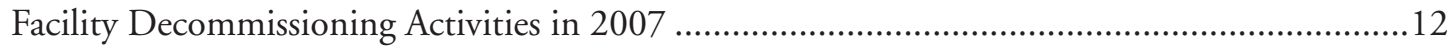

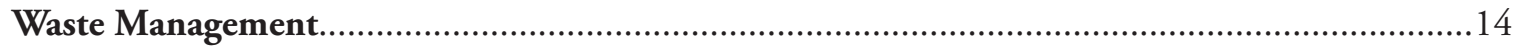

Washington State Initiative 297: Cleanup Priority Act ............................................................. 18

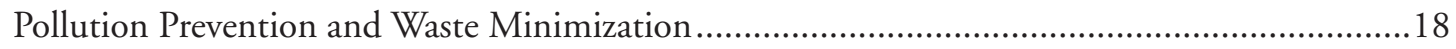

Environmental and Resource Protection Programs ...............................................................19

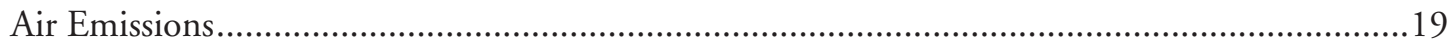

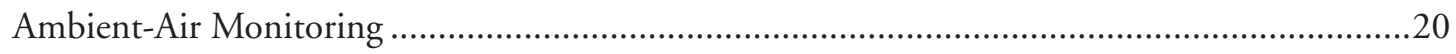

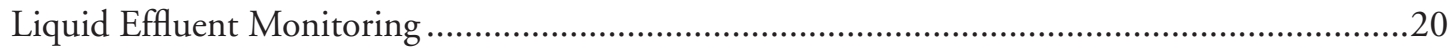

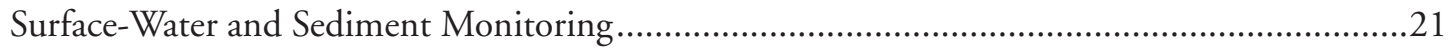

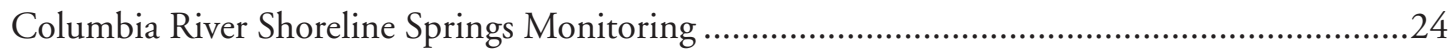

Radiological Monitoring of Hanford Site Drinking Water ....................................................25

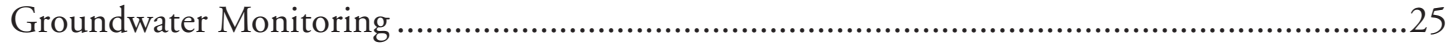

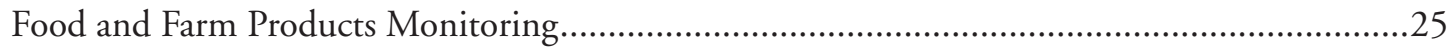




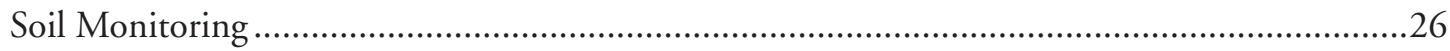

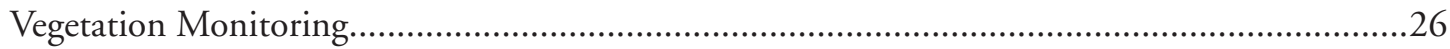

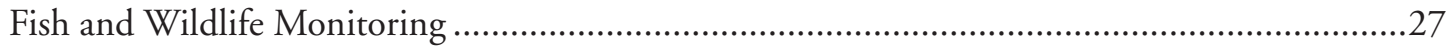

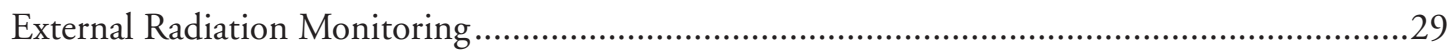

Potential Radiological Doses from 2007 Hanford Operations.................................................29

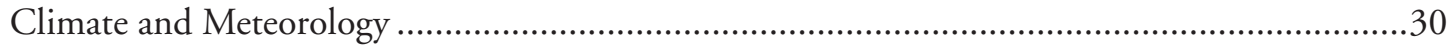

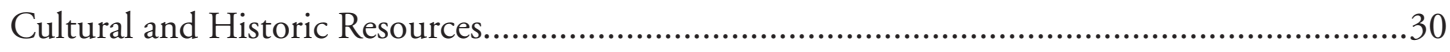

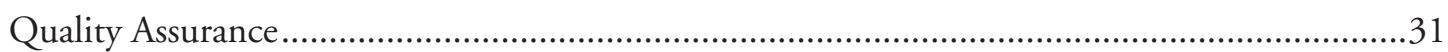




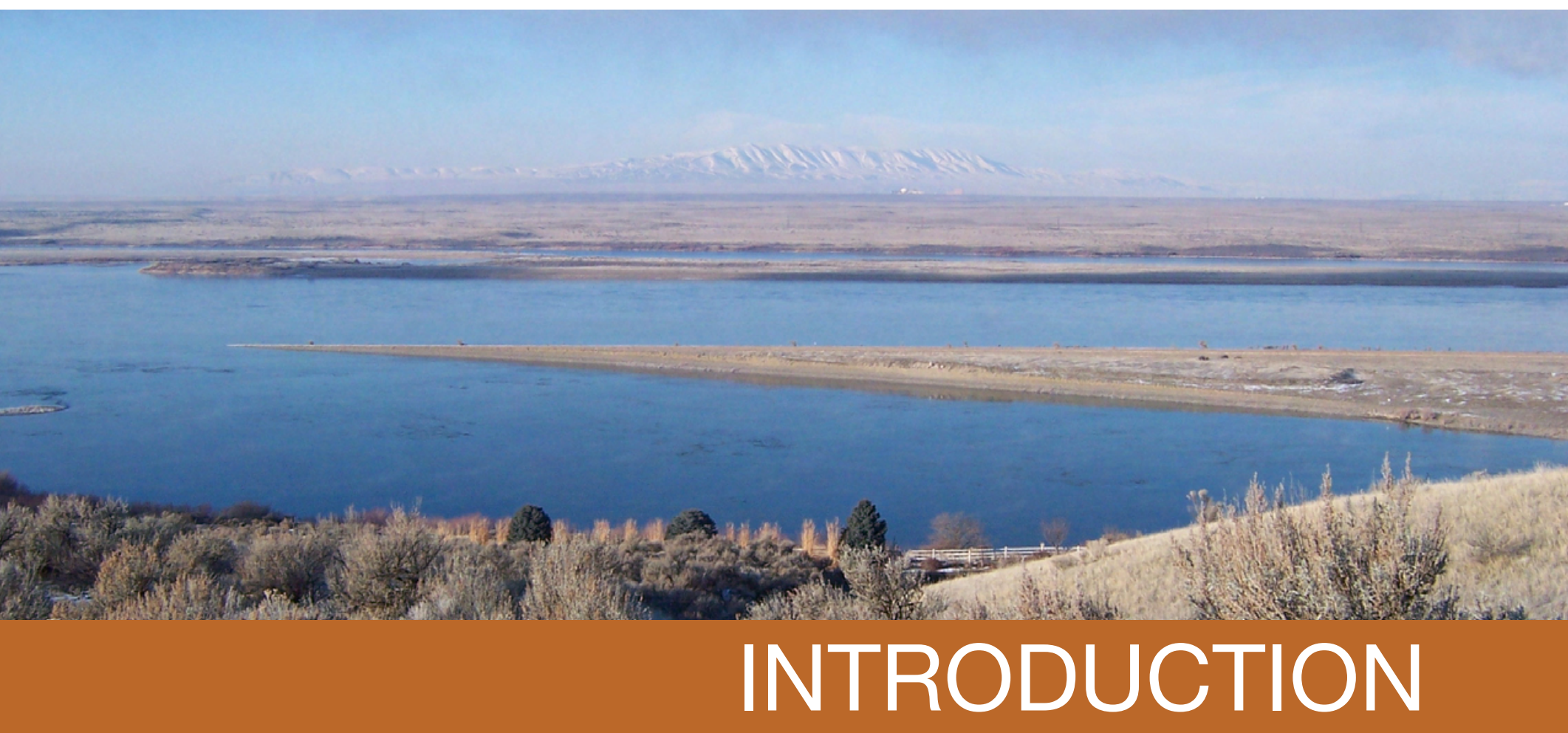

This booklet summarizes the Hanford Site Environmental Report for Calendar Year 2007. The Hanford Site environmental report, published annually since 1959, includes information and summary data that provide an overview of activities at the U.S. Department of Energy's (DOE) Hanford Site.

Included in this booklet are brief descriptions of the Hanford Site and its mission, the status and results of cleanup and facility decommissioning activities, environmental monitoring and surveillance programs and activities, and estimated radiological doses to the public and biota from 2007 Hanford Site activities. This booklet was written with a minimum of technical terminology. Readers interested in more detailed information can consult the 2007 Hanford Site environmental report or the technical documents cited and listed in that report. This booklet and the report are available online at http://hanford-site.pnl.gov/envreport/.

The Columbia River flows through the northern portion of the Hanford Site and forms part of the site's eastern boundary. 


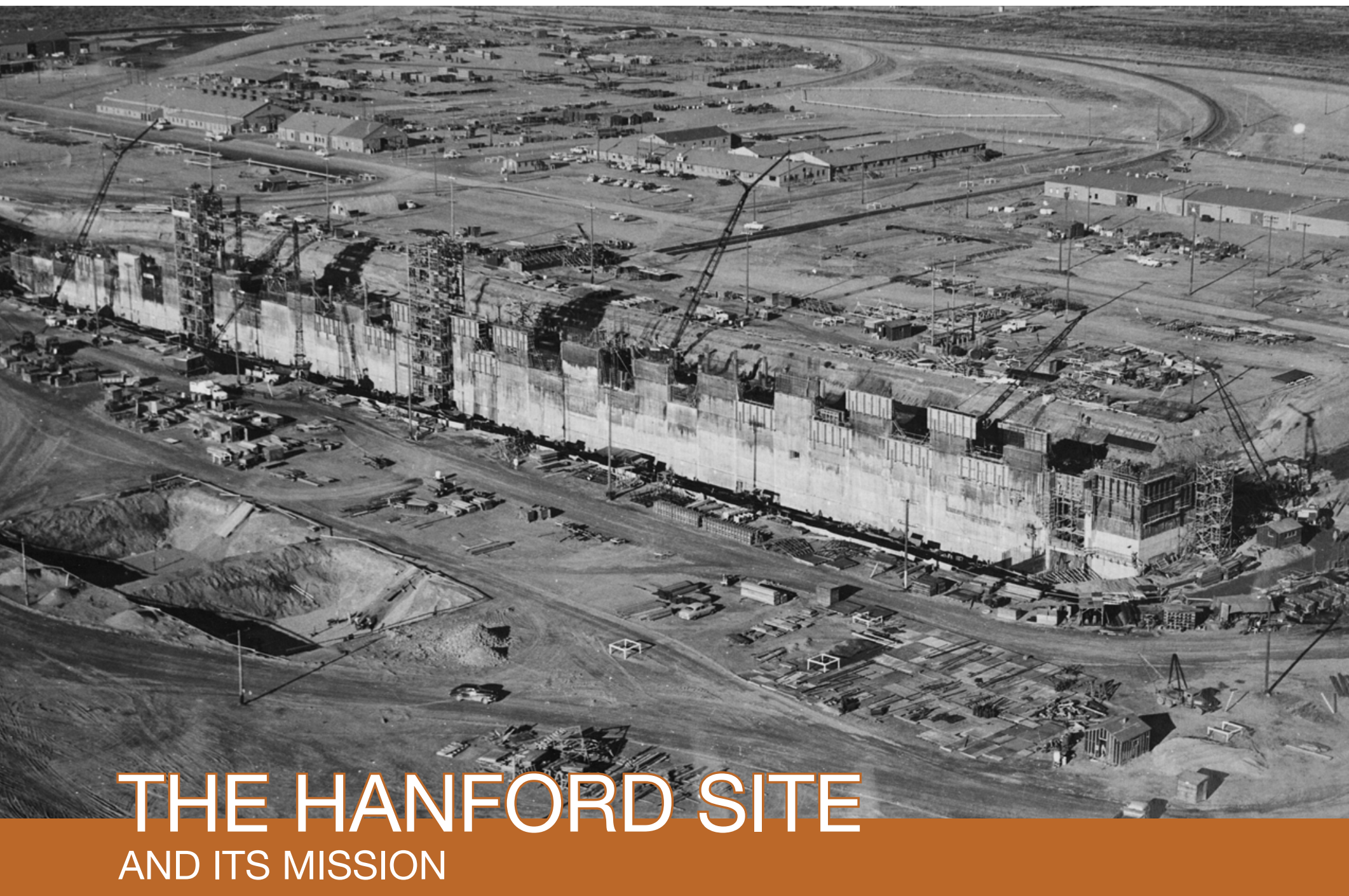

Construction of the Plutonium-Uranium Extraction Plant in the 200-East Area was completed in 1955.

The Hanford Site, the first nuclear production facility in the world, was established in 1943 to produce plutonium for national defense. The site was selected by the U.S. Corps of Engineers because of its remoteness and because it had abundant electrical power from Grand Coulee Dam, a functional railroad, clean water from the Columbia River, and available sand and gravel for construction. During the next 21 years, nine plutonium-production reactors were constructed by DOE on the Hanford Site, along with facilities to separate and purify the reactor products into required forms. One reactor operated beyond the early 1970s; all were decommissioned by the late 1980s.

In the late 1970s, the federal government constructed the Fast Flux Text Facility, a liquid-sodium-cooled nuclear reactor on the Hanford Site to test advanced nuclear fuels, materials, and components. This reactor operated 
until April 1992 and deactivation and decommissioning activities began in December 2001.

Today, under the direction of DOE, the Hanford Site is engaged in the world's largest environmental remediation and cleanup project, collaborating with technical, regulatory, cultural, financial, and political groups and representatives.

Non-DOE operations and activities on Hanford Site leased land include commercial power production by Energy Northwest at the Columbia Generating Station and operation of a commercial low-level radioactive waste burial site by US Ecology Washington, Inc. The Laser Interferometer Gravitational Wave Observatory (LIGO) is located west of the 400 Area and is operated jointly by the California and Massachusetts Institutes of Technology and sponsored by the National Science Foundation.

\section{SITE DESCRIPTION}

The Hanford Site lies within the semi-arid

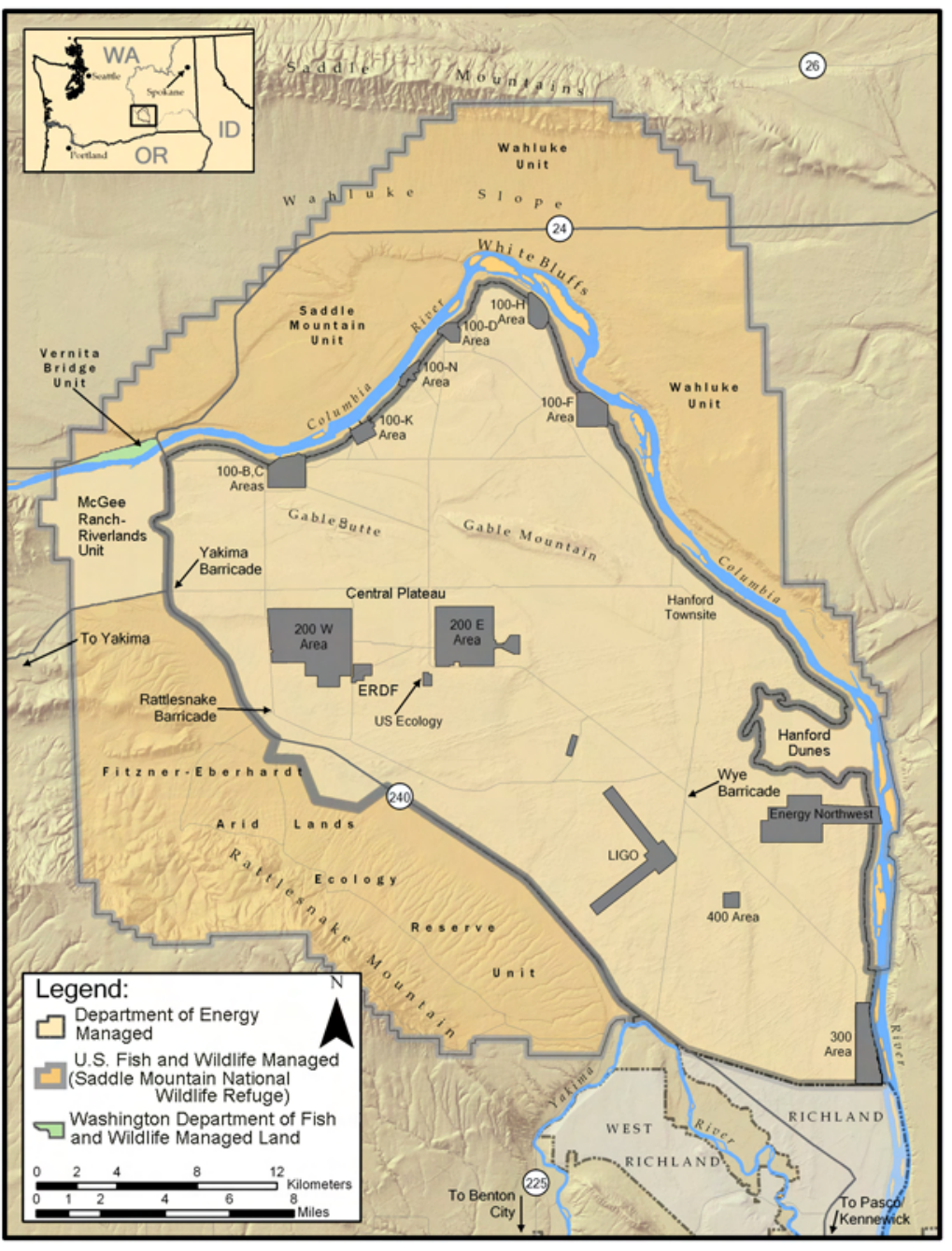

Pasco Basin of the Columbia Plateau in southeastern Washington State. The site, a relatively undeveloped area of shrub-steppe habitat (a drought-resistant,

This map shows management units on the Hanford Reach National Monument and the operational areas of the Hanford Site. shrub and grassland ecosystem) containing a rich diversity of plant and animal species, occupies an area of approximately 586-square miles located north of the city of Richland. Public access to much of the site is restricted, and its large land area provides a buffer for the smaller areas on the site that historically were used for production of nuclear materials, waste storage, and waste disposal. The Columbia River flows eastward through the northern part of the Hanford Site and then turns south, forming part of the eastern site boundary.

In June 2000, the Hanford Reach National Monument was established on the site by Presidential Proclamation to protect the nation's only unimpounded stretch of the Columbia River above Bonneville Dam in the United States, as well as the remaining shrub-steppe ecosystem that once blanketed the Columbia River Basin. In 2007, the DOE, U.S. Fish and Wildlife Service, The Hanford Site lies within the semi-arid Pasco Basin of the Columbia Plateau in southeastern Washington State. and Washington Department of Fish and Wildlife each managed units of the monument. 


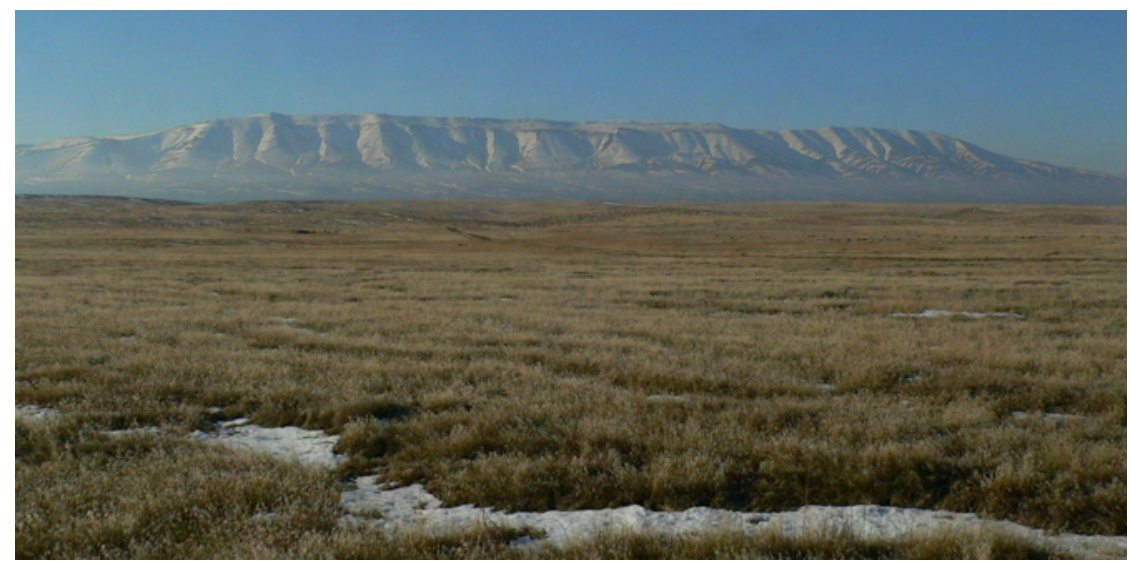

Rattlesnake Mountain, rising to 3,525 feet above sea level, is part of the Fitznerl Eberhardt Arid Lands Ecology Reserve Unit of the Hanford Reach National Monument. (Photo courtesy of Kyle Larson, Pacific Northwest National Laboratory.)
The major DOE operational, research, and administrative areas on and around the Hanford Site include the following:

- 100 Areas - The 100 Areas, situated along the shore of the Columbia River in the northern portion of the site, were the location of nine nuclear reactors that have since been retired. The 100 Areas occupy approximately 4 square miles.

- 200-West and 200-East Areas These areas are located on the Central Plateau, approximately 5 and 7 miles, respectively, south and west of the Columbia River. The plateau surface is approximately 328 feet above the level of the Columbia River and about 280 feet above the underlying water table. These areas contain underground waste storage tanks and housed facilities (known as "separations plants") that extracted plutonium from dissolved irradiated fuel. The 200-East and 200-West Areas cover approximately 6 square miles.

- 300 Area - The 300 Area is located just north of the city of Richland and covers approximately 0.6 square mile. From the early 1940s until the advent of the cleanup mission, nuclear fuel fabrication and research and development activities at the Hanford Site were performed in the 300 Area.

\section{HANFORD SITE AT A GLANCE}

\section{Location}

Dominant Features

Size

Employees

Mission

Site Management
The U.S. Department of Energy's Hanford Site is located in southeastern Washington State near the city of Richland.

Rattlesnake Mountain on the Fitzner/Eberhardt Arid Lands Ecology Reserve Unit of the Hanford Reach National Monument rises 3,525 feet above sea level, and the Columbia River flows through the northern part of the site.

The site covers approximately 586 square miles.

DOE and its contractors employed approximately 12,000 workers in 2007.

The Hanford Site mission is to safely clean up and manage the site's facilities and waste, and reduce the size of the site by releasing the land for other uses.

DOE's Richland Operations Office and Office of River Protection jointly manage the central portion of the Hanford Site through several contractors and their subcontractors. DOE, U.S. Fish and Wildlife Service, and Washington Department of Fish and Wildlife each manage units of the Hanford Reach National Monument. 
- 400 Area - The 400 Area is located northwest of the 300 Area, and covers approximately 0.23 square mile. It is the location of the Fast Flux Test Facility, which has not operated since 1992 and was undergoing deactivation and decommissioning during 2007. This nuclear reactor was designed and used to test various types of nuclear fuel, produce medical and industrial isotopes, and conduct cooperative international research.

- 600 Area - The 600 Area includes all of the Hanford Site not occupied by the 100, 200, 300, and 400 Areas.

- Former 1100 Area - The former 1100 Area is located between the 300 Area and the city of Richland. In 1998, this area was transferred to the Port of Benton as part of the DOE Richland Operations Office economic diversification efforts and is no longer part of the Hanford Site. DOE contractors continue to lease facilities in this area.

- Richland North Area (off the site) - This area includes the Environmental Molecular Sciences Laboratory, Pacific Northwest National Laboratory, and other DOE and contractor facilities (mostly office buildings), generally located in the northern part of the city of Richland.

- 700 Area (off the site) - The 700 Area includes DOE administrative buildings in the central part of the city of Richland.

- Volpentest Hazardous Materials Management and Emergency Response Training and Education Center (also called HAMMER) - This worker safety-training facility is located on the site near the city of Richland. It consists of an 80-acre main site and a 10,000-acre law enforcement and security-training site. The facility is owned by DOE, managed by Fluor Hanford, Inc., and used by site contractors, federal and state agencies, tribal governments, and private industries.

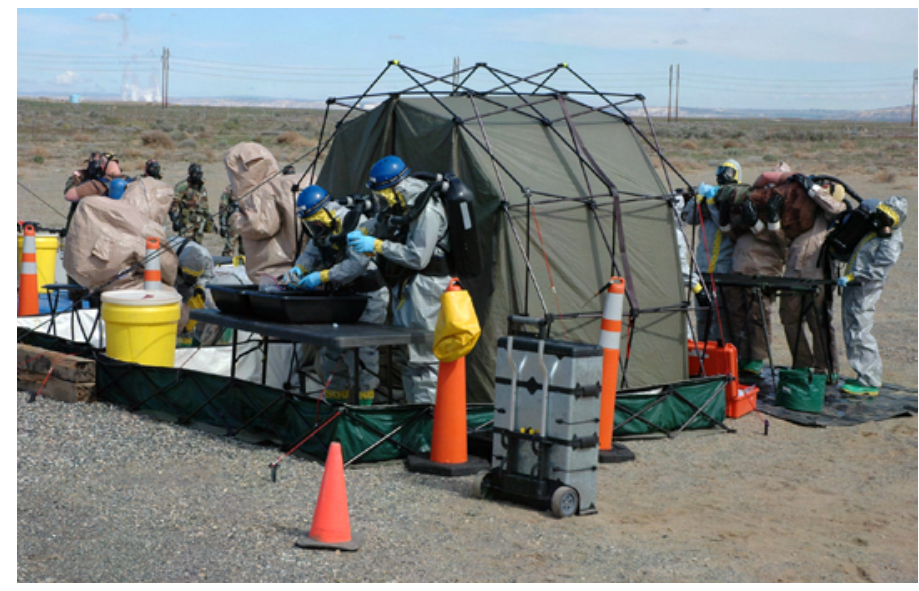

\section{HANFORD SITE MISSION}

For more than 40 years, Hanford Site facilities were dedicated primarily to the production of plutonium for national defense and management of the resulting waste. In recent years, efforts at the site have focused on developing new waste treatment and disposal technologies, and the characterization and clean up of contamination due to historical operations. Physical challenges at the Hanford Site include managing or cleaning up millions of gallons of highly radioactive liquid waste in 177 underground storage tanks, 2,300 tons of spent nuclear fuel, 9 tons of plutonium in various forms, about 25 million cubic feet
Worker safety and security training occurs at the Volpentest Hazardous Materials Management and Emergency Response Training and Education Center on the Hanford Site. 
The DOE's primary

mission at the

Hanford Site is to

clean up facilities

and contamination

left from historical

operations. of buried or stored solid waste, more than 1,700 former waste-disposal sites, and about 500 contaminated facilities.

Currently, DOE's primary mission is environmental remediation and cleanup, including the remediation of contaminated areas and the decontamination and decommissioning of Hanford Site facilities. The Performance Management Plan for the Accelerated Cleanup of the Hanford Site states that the cleanup mission includes the following strategies:

- Restoring the Columbia River corridor by accelerating the cleanup of Hanford Site sources of radiological and chemical contamination that threaten the air, groundwater, or Columbia River. It is expected that most river corridor projects will be completed by 2012 .

- Ending the tank waste program by 2033 by accelerating waste retrieval, increasing the capacity of the Hanford Tank Waste Treatment and Immobilization Plant (under construction), and continuing the process of closing underground waste storage tanks.

- Accelerating treatment and disposal of mixed low-level waste and the retrieval of transuranic waste and its shipment off the site.

- Accelerating cleanup of excess facilities on the Central Plateau (200-East and 200-West Areas).

- Accelerating cleanup and protection of groundwater beneath the Hanford Site.

- Clean up of other Hanford Site facilities considered urgent risks.

Between 1943 and 1985, 177 radioactive waste storage tanks were built at the Hanford Site. The current mission includes managing and treating this waste. jointly manage the Hanford Site through several contractors and their
The DOE Richland Operations Office and DOE Office of River Protection subcontractors. The DOE Richland Operations Office manages the cleanup of waste from historical operations, research, and other programs at the Hanford Site. The DOE Office of River Protection manages DOE's largest, most complex environmental cleanup project - retrieval, treatment, and disposal of tank waste at the Hanford Site. 


\section{COMPLIANCE WITH FEDERAL ACTS AT THE HANFORD SITE IN 2007}

\section{Regulation}

American Indian Religious

Freedom Act; Antiquities Act

of 1906; Archaeological and

Historic Preservation Act of

1974; Archaeological Resources

Protection Act of 1979; Historic

Sites, Buildings, and Antiquities

Act; National Historic Preservation

Act; and Native American Graves

Protection and Repatriation Act

Atomic Energy Act of 1954
Proper management of radio-

active materials.

\section{What It Covers}

Cultural resources.

Air quality, including emissions from facilities and from unmonitored sources.

\section{Status}

During 2007, 129 cultural resource reviews were requested on the Hanford Site. DOE determined that 115 activities would not affect cultural resources and were exempt from further review; 14 requests required full reviews. Thirty-four cultural resources sites were visited in 2007 to assess the effects of erosion, weathering, and unauthorized excavation and collection. Sixteen new archaeological sites and 23 new isolated finds were recorded on the Hanford Site in 2007 . Two data recovery excavations were also conducted in advance of project initiation.

In 2007, five DOE regulations and directives pertaining to the management and control of radioactive materials on the Hanford Site were issued or underwent significant revision. In addition, six technical standards underwent significant revisions.

Clean Air Act

The Hanford Site air operating permit was reissued by the Washington State Department of Ecology in December 2006 Three revisions to the air operating permit were approved in 2007. The Benton Clean Air Agency regulates open-air burning and oversees asbestos regulation compliance. The Washington State Department of Health, the Washington State Department of Ecology, and the Benton Clean Air Agency conducted over 45 inspections in 2007.

Clean Water Act of 1977

Point-source discharges to

The Hanford Site has one National Pollutant Discharge

U.S. surface waters. Elimination System Permit, one storm water permit, and severa state sanitary wastewater discharge permits. There were no permit violations in 2007.

Comprehensive Environmental

Response, Compensation, and

Liability Act of 1980 (CERCLA)
Sites already contaminated by hazardous materials.

Institutional controls are implemented and maintained in accordance with CERCLA decision documents. During 2007, there were no CERCLA institutional controls at the Central Plateau that required review. The River Corridor Project performed an inspection of remediation sites in the 100 Areas, as well as a review of events, permits, and 300 Area institutional controls implemented as a result of the 2006 review. There were several minor spills on the Hanford Site in 2007 and one spill resulting in a penalty to DOE under the Tri-Party Agreement.

Emergency Planning \& Community Right to Know Act of 1986
The public's right to information about hazardous materials in the community and the establishment of emergency planning procedures.
In early 2008, Hanford Site officials issued the 2007 Hanford Site Tier Two Emergency and Hazardous Chemical Inventory report (DOE/RL-2008-14, Rev. 0) to the Washington State Department of Ecology's Community Right To Know Unit; local emergency planning committees for Benton, Franklin, and Grant Counties; and both the city of Richland and Hanford Site fire departments. The 2007 Hanford Site Toxic Chemical Release Inventory is scheduled for release in 2008 .

Numerous plants and animals at the Hanford Site are federal- or state-listed as endangered, threatened, sensitive, or candidate species. Ecological compliance reviews are conducted prior to project initiation at the Hanford Site to prevent adverse impacts to biological resources, including listed species. In 2007, 179 reviews were performed, including 99 ecological compliance reviews for general site activities and 80 reviews for environmental restoration activities.

At the Hanford Site, pesticides are applied by commercial pesticide operators licensed by the state.

Rodenticide Act of 1975

Migratory Bird Treaty Act
Storage and use of pesticides.

Migratory birds or their feathers, nests, or eggs.
All Hanford Site projects with a potential to affect federal- or state-listed species of concern were in compliance with the requirements of this act by using an ecological compliance review process to minimize adverse impacts to migratory birds. 


\section{COMPLIANCE WITH FEDERAL ACTS AT THE HANFORD SITE IN 2007}

\section{Regulation}

National Environmental Policy Act of 1969 (NEPA)
What It Covers

2007 Status
Environmental impact statements for major federal projects that have the potential to significantly affect the quality of the human environment.
Resource Conservation and Recovery Act of 1976 (RCRA)
Tracking hazardous waste from generator to treatment, storage, or disposal (referred to as cradle-tograve management).
Safe Drinking Water Act of 1974
Drinking water systems.

Hazardous chemical regulation and tracking; primarily polychlorinated biphenyls (PCBs).
A draft comprehensive conservation plan and environmental impact statement for the Hanford Reach National Monument/ Saddle Mountain National Wildlife Refuge was issued for review in December 2006. The public comment period ended in March 2007 and the final environmental impact statement was being finalized during 2007 for issuance in 2008. A draft environmental impact statement for Hanford Site Tank Closure and Waste Management was in process during 2007 and scheduled for issuance in 2008.

In January 2007, DOE issued a notice of intent to prepare a programmatic environmental impact statement for the Global Nuclear Energy Partnership Initiative. In July 2007, DOE announced its intent to prepare an environmental impact statement for the disposal of Greater-Than-Class-C low-level radioactive waste. A draft environmental impact statement to develop and evaluate alternatives that could create additional water storage for the Yakima River Basin, assess the potential to improve anadromous fish habitat, improve the reliability of the Yakima Project irrigation water supply during dry years, and provide water to meet future demand for municipal water supplies was issued in January 2008. DOE is preparing a supplemental analysis to the 1999 Hanford Comprehensive Land-Use Plan Environmental Impact Statement to evaluate whether a supplement environmental impact statement or a new environmental impact statement is required.

DOE is operating under an expired facility RCRA permit at the Hanford Site while the Washington State Department of Ecology drafts a new permit. During 2007, seven revisions to the Hanford Facility RCRA Permit Part A Form and one RCRA Part B Permit application were submitted to the state for review and approval. Two revisions to the RCRA permit were issued by Washington State Department of Ecology and three treatment, storage, and disposal units were approved for closure. Two RCRA noncompliance documents were received at the Hanford Site in 2007: 1) violations of the RCRA permit at the 183-N demolition site, and 2) violations of state and federal hazardous waste tank system regulations for operation of temporary mixed waste transfer lines in use at Hanford Site tank farms. Resolution is ongoing.

There were nine public drinking water systems on the Hanford Site in 2007 . The systems were monitored for radiological and chemical contaminants and disinfection residuals and byproducts. There were no microbiological detections during 2007 and all chemical concentrations in Hanford Site drinking water were well below the maximum contaminant levels established by the EPA. Systems demonstrated compliance with the filtration and disinfection treatment technique requirements and limits for disinfectant residuals and disinfection byproducts.

Toxic Substances Control Act

During 2007, the 2006 Polychlorinated Biphenyl Annual Document Log - Report for the Hanford Site and a 2006 PCB annual report were submitted to the EPA as required. EPAapproved risk-based disposal approvals were used in 2007 for retrieving waste from selected single-shell underground waste storage tanks, for the removal of containers of treated sludge from the K-East basin, and continued storage of two water tower tanks containing PCB-contaminated paint. 


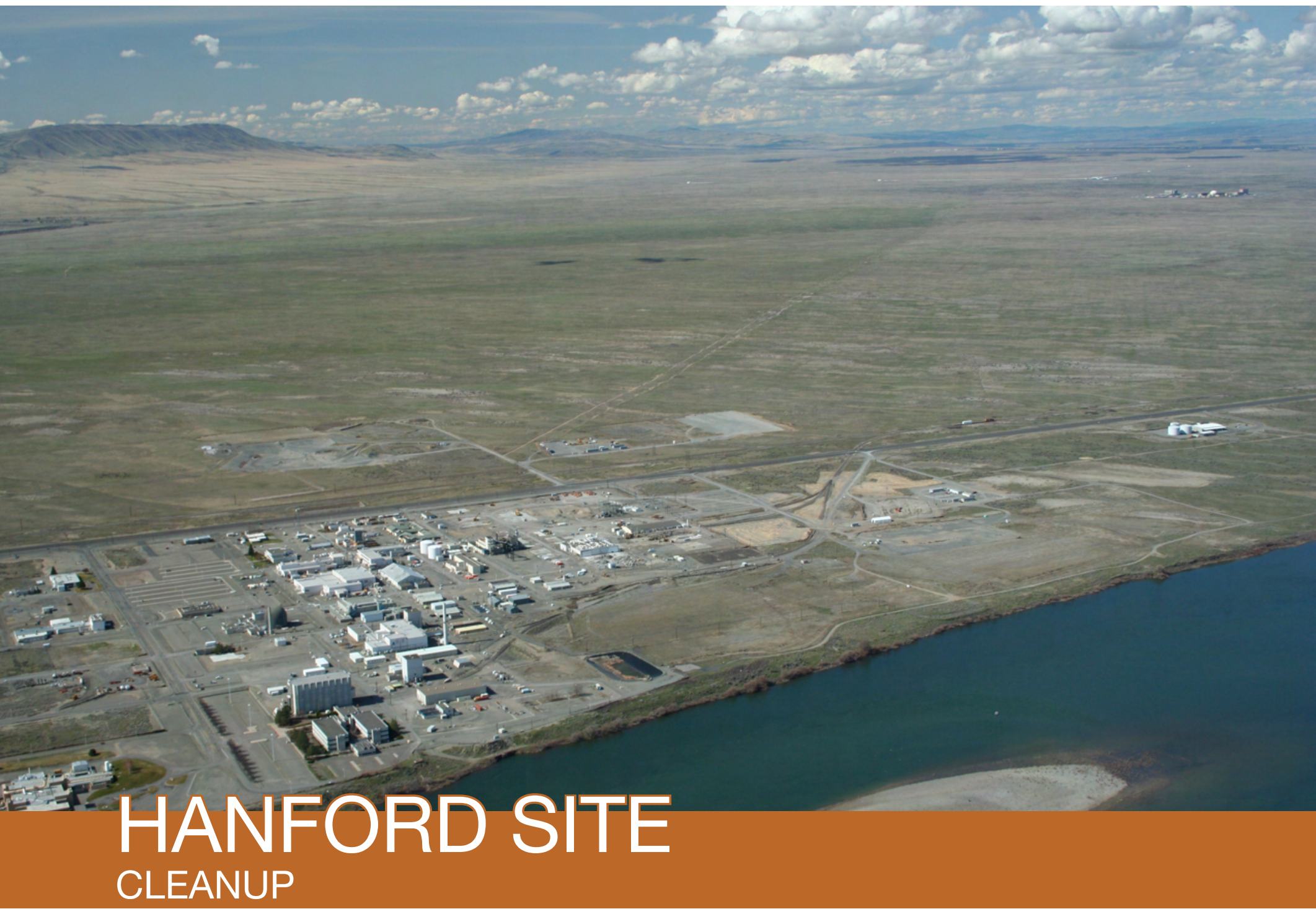

Cleanup of the 300 Area continued during 2007 with the removal of 370 tons of contaminated soil.

Hanford Site cleanup includes remediation of former waste-disposal sites and decommissioning of inactive facilities.

\section{CLEANUP OPERATIONS IN 2007}

Since cleanup activities began at the Hanford Site, the primary focus has been on former liquid effluent waste-disposal sites. After nearly 10 years of work, the number of liquid effluent waste-disposal sites requiring remediation has been reduced, and cleanup activities are now turning to remediation of waste burial grounds. The volume of contamination in waste burial grounds is less than in liquid effluent waste-disposal sites; however, the burial grounds may contain 
unknown materials and additional time may be required to characterize the materials and dispose of them properly.

\section{Remediation of Waste Sites in the} 100 Areas. Full-scale remediation of waste sites began in the 100 Areas in 1996. In 2007, remediation focused on waste burial grounds and miscellaneous waste sites in the 100-B/C, 100-K, 100-D, and 100-F Areas. A total of 388,200 tons of contaminated soil from 100 Area's remediation activities was disposed of at the Environmental Restoration Disposal Facility (near the 200-West Area) during 2007. The bulk of the contaminated soil was from the 100-D and 100-F Areas. Several cleaned up waste sites in the 100-B/C and 100-F Areas were revegetated with native grass seed and sagebrush seedlings in 2007.

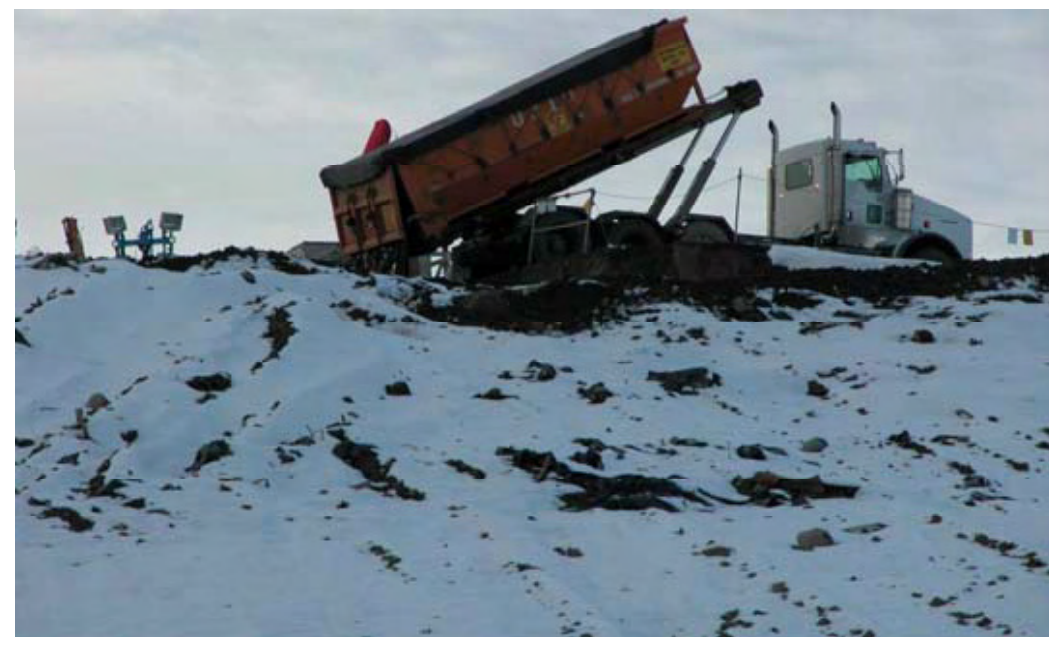

Contaminated soil from 100 Areas remediation was disposed at the Environmental Restoration Disposal Facility.

K Basins Closure Activities. During 2007, workers continued to clean out the $\mathrm{K}$ Basins, which are two indoor, concrete pools attached to the now-closed

\section{SUMMARY OF GROUNDWATER REMEDIATION ACTIVITIES}

\begin{tabular}{|c|c|c|c|c|}
\hline Location & $\begin{array}{l}\text { Startup } \\
\text { Date }\end{array}$ & Contaminant & $\begin{array}{c}\text { Mass Removed } \\
\underline{2007}\end{array}$ & $\begin{array}{l}\text { Mass Removed } \\
\text { Since Startup }\end{array}$ \\
\hline $\begin{array}{l}\text { 100-D Area (100-DR-5 Pump- } \\
\text { and-Treat System) }\end{array}$ & 2004 & Chromium & 121 pounds & 353 pounds \\
\hline $\begin{array}{l}\text { 100-D Area (100-HR-3-D } \\
\text { Pump-and-Treat System) }\end{array}$ & 1997 & Chromium & 47 pounds & 581 pounds \\
\hline $\begin{array}{l}\text { 100-H Area (100-HR-3-H } \\
\text { Pump-and-Treat System) }\end{array}$ & 1997 & Chromium & 5 pounds & 108 pounds \\
\hline $\begin{array}{l}\text { 100-K Area (100-KR-4 Pump- } \\
\text { and-Treat System) }\end{array}$ & 1997 & Chromium & 44 pounds & 688 pounds \\
\hline $\begin{array}{l}\text { 100-K Area (Pump-and-Treat } \\
\text { System near K-West Reactor) }\end{array}$ & 2007 & Chromium & 34.8 pounds & 34.8 pounds \\
\hline $\begin{array}{l}\text { 200-West Area (200-ZP-1 } \\
\text { Pump-and-Treat System) }\end{array}$ & 1994 & Carbon tetrachloride & 1,665 pounds & 24,150 pounds \\
\hline \multirow{4}{*}{$\begin{array}{l}\text { 200-West Area (200-UP-1 } \\
\text { Pump-and-Treat System) }\end{array}$} & 1994 & Carbon tetrachloride & 0.12 pound & 76.3 pounds \\
\hline & & Nitrate & 785 pounds & 77,320 pounds \\
\hline & & Technetium-99 & 0.01 ounce & 0.263 pound \\
\hline & & Uranium & 2.5 pounds & 469 pounds \\
\hline $\begin{array}{l}\text { Waste Management } \\
\text { Area S-SX }\end{array}$ & 2003 & Technetium-99 & 0.001 ounce & 0.011 ounce \\
\hline $\begin{array}{l}\text { 200-West Area (Soil-Vapor } \\
\text { Extraction System) }\end{array}$ & 1991 & Carbon tetrachloride & 661 pounds & 175,000 pounds \\
\hline
\end{tabular}




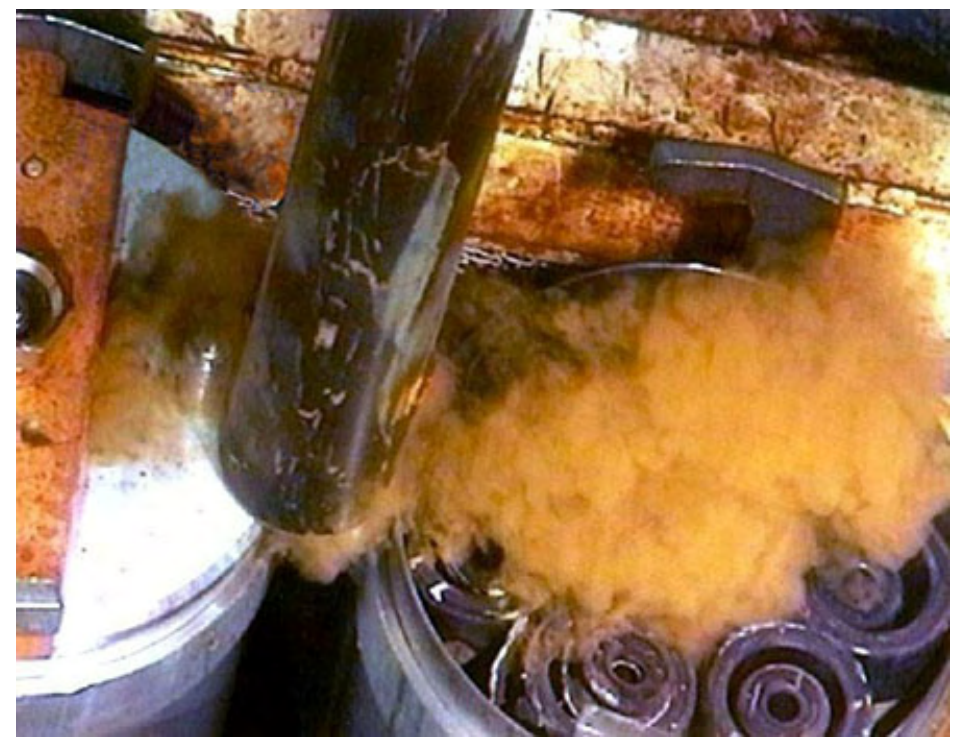

Sludge is visible from an aging fuel canister once located in the K-East Basin.

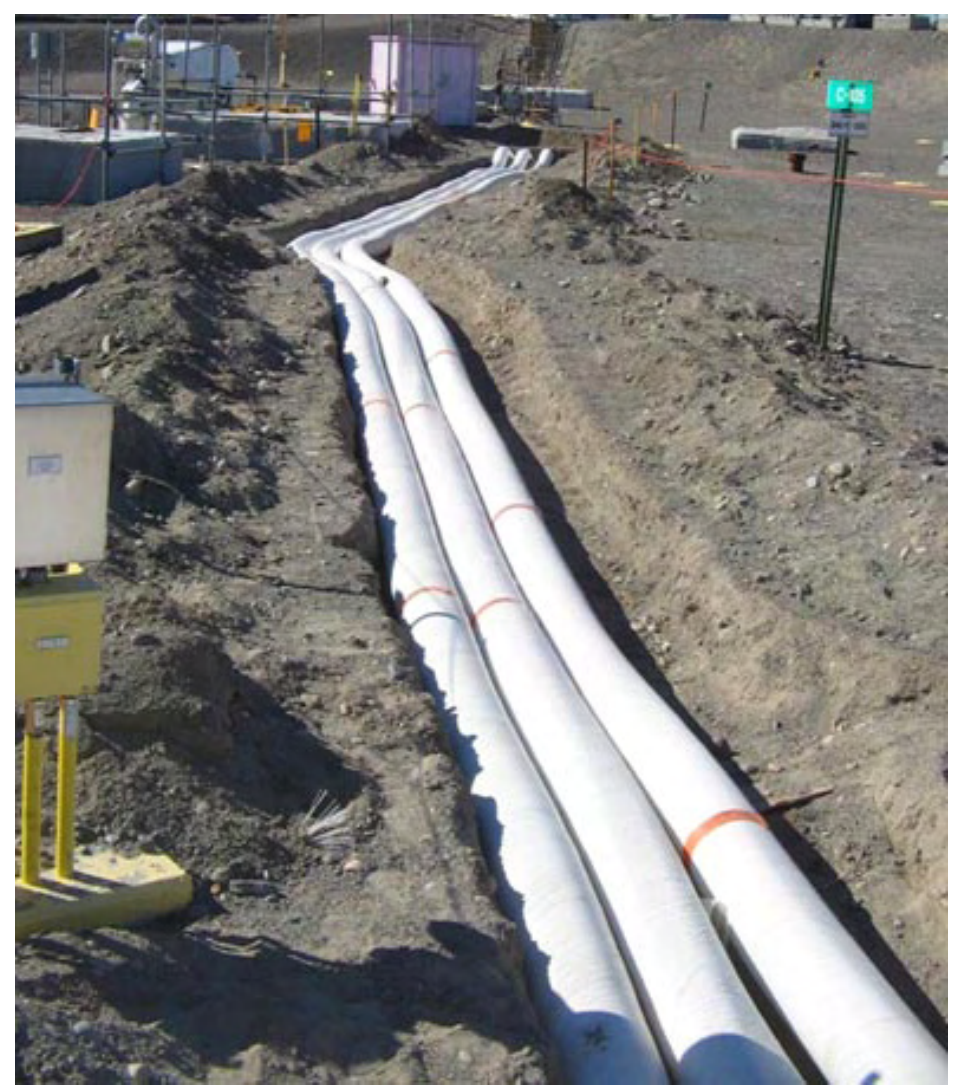

A hose-in-hose transfer system was used to transfer sludge from the $K$-East Basin to the K-West Basin.
K-East and K-West Reactors. For nearly 30 years, these basins contained 2,300 tons of Hanford Site $\mathrm{N}$ Reactor spent fuel and a small quantity of irradiated single-pass reactor fuel from older site reactors. This fuel was removed in a major effort that ended in 2004 but fuel corrosion left behind sludge and debris. During 2007, over 100 tons of debris and fuel racks from both $\mathrm{K}$ Basins was removed, packaged, and readied for shipment to the Environmental Restoration Disposal Facility. Also, all remaining sludge was removed from K-East Basin, allowing the start of deactivation and decommissioning.

Remediation of Waste Sites in the 200 Areas. Remedial investigation or feasibility study activities continued during 2007 at waste sites in the 200 Areas that are grouped into a number of CERCLA operable unit groups.

Remediation of Waste Sites in the 300 Area. In 2007, 370 tons of contaminated soil from 300 Area waste sites were removed and disposed of at Hanford's Environmental Restoration Disposal Facility. A design solution for cleaning up the 618-10 and 618-11 Burial Grounds was submitted to DOE in December 2006; site characterization was recommended.

\section{FACILITY DECOMMISSIONING ACTIVITIES IN 2007}

\section{Decommissioning of Facilities in the 100 Areas.}

Decontamination and decommissioning activities focused on the 100-N Area in 2007, where 12 facilities were demolished. A removal action work plan for the 105-K-East and 105-K-West Reactor facilities was approved in February 2007 by DOE and EPA. 
Decommissioning of Facilities in the 200 Areas. Activities to decontaminate and deactivate the processing facilities at the Plutonium Finishing Plant continued. Surveillance, maintenance, and decontamination or stabilization of over 500 waste sites in the 200-East, 200-West, and 200-North Areas, and a few waste sites on the Fitzner/Eberhardt Arid Lands Ecology Reserve Unit, continued. Periodic surveillances, radiation surveys, and herbicide applications were performed.

Decommissioning of Facilities in the $\mathbf{3 0 0}$ Area. During 2007, 300 Area deactivation, decontamination, decommissioning, and demolition activities focused on removing facilities and buildings. More than 24 facilities and buildings were demolished in the 300 Area in 2007.

Decommissioning of Facilities in the 400 Area - Fast Flux Test Facility. After multiple studies, a final decision was made to complete facility deactivation, including removing all nuclear fuel, draining the liquid-sodium systems, and deactivating systems and equipment to

\section{What is decommissioning?}

When DOE declares a facility as surplus (no longer needed), it is shut down and prepared for decontamination and decommissioning (D\&D). The process is the safe decontamination, dismantling, removal of contamination and structures, and/or the release for reuse of facilities that are no longer active. DOE is conducting $D \& D$ activities on reactors, processing plants, storage tanks, laboratory facilities, and other structures. Decontamination and decommissioning presents many challenges. Work continues at the Hanford Site to decommission facilities in the operational areas.

Adapted from

http://www.em.doe.gov/DandD/DD.aspx place the facility in a low-cost, long-term surveillance and maintenance condition by September 2009. During 2007, fuel removal from the 400 Area Property Protected Area continued. The remaining mixed-oxide fuel assemblies were removed, processed, and placed in interim spent nuclear fuel storage casks. A RCRA treatment, storage, and disposal permit for container storage of more than 90 days was issued by the Washington State Department of Ecology in November 2007, for the storage of liquid sodium recovered from the Fast Flux Test Facility. Deactivation activities continued in 2007, including the removal or replacement of transformers containing polychlorinated biphenyls, the shutdown of electric, water, fire suppression and ventilation systems, and the cleanout of the reactor containment building and supporting facilities.

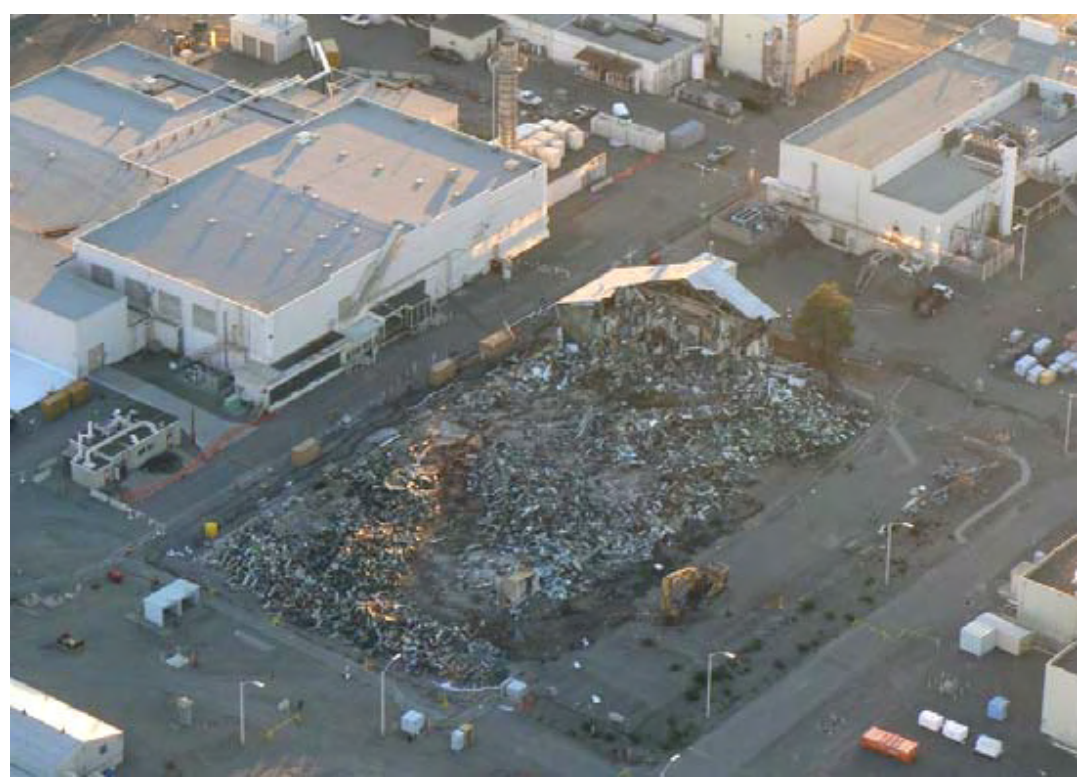

The 328 Building was 1 of 24 facilities and buildings demolished in the 300 Area in 2007. 


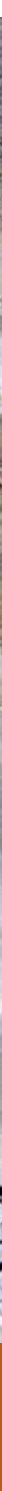

The Environmental Restoration Disposal Facility, located adjacent to the 200-West Area, was constructed to RCRA minimum technology requirements, including a double liner and leachate collection system.
Hanford Site cleanup activities generate non-regulated, radioactive, nonradioactive, mixed, and hazardous waste. Mixed waste has both radioactive and hazardous non-radioactive substances. Hazardous waste contains either dangerous waste or extremely hazardous waste, or both. This waste is handled and prepared for safe storage at the site or shipped to offsite facilities for treatment and disposal.

In addition to newly generated waste, significant quantities of waste remain from years of nuclear materials production and waste management activities. Most waste from past operations at the Hanford Site resides in underground storage tanks and in former waste-disposal sites, or is temporarily stored until it can be cleaned up, disposed, or placed in permanent safe storage. 
Management of Solid Waste. Waste management at the Hanford Site in 2007 included the treatment, storage, and disposal of solid waste. Onsite solid waste facilities include the Central Waste Complex, Waste Receiving and Processing Facility, T Plant Complex, Environmental Restoration Disposal Facility, Radioactive Mixed Waste Disposal Facility, and low-level burial grounds.

The Central Waste Complex can store as much as 27,200 cubic yards of waste. This capacity is adequate to store the projected volumes of lowlevel, transuranic, and mixed waste, and radioactively contaminated polychlorinated biphenyls to be generated from Hanford Site cleanup activities assuming on-schedule treatment of the stored waste. Treatment will reduce the amount of

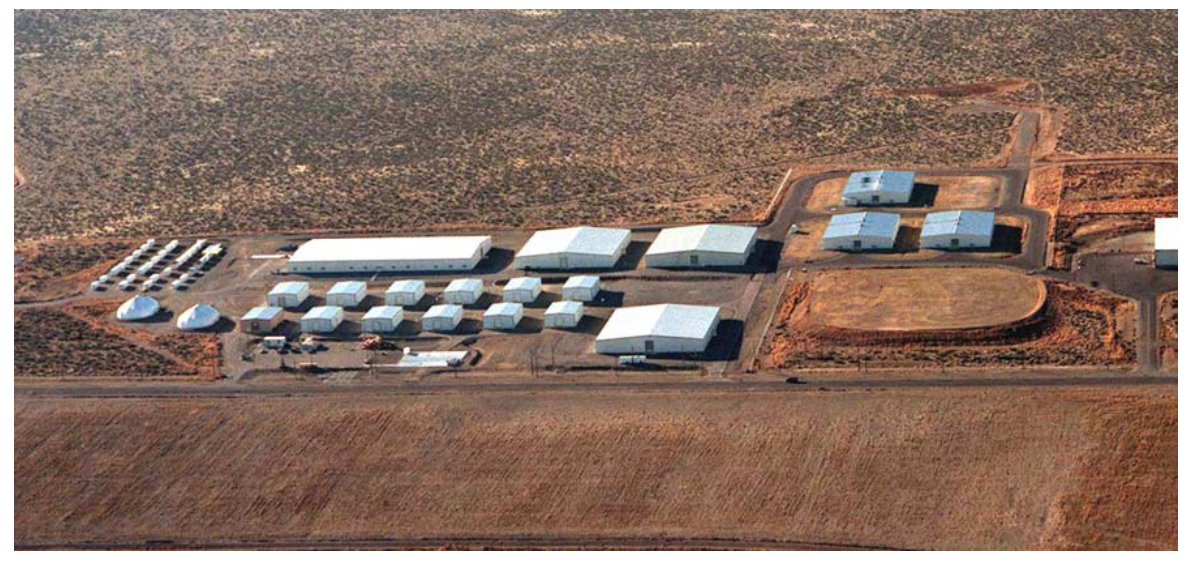
waste in storage and make room for newly generated mixed waste. The current volume of waste stored at this complex totals approximately 10,300 cubic The Central Waste Complex currently stores 10,300 cubic yards of waste. yards.

Waste destined for the Waste Receiving and Processing Facility includes stored waste as well as newly generated waste from current site cleanup activities. The waste consists primarily of contaminated cloth, paper, rubber, metal, and plastic. This facility treated and shipped 904 cubic yards of waste offsite in 2007.

The T Plant Complex in the 200-West Area provides waste treatment, storage, and decontamination services for the Hanford Site and for offsite facilities. In 2007, eight-hundred, fifty-seven 55-gallon drum equivalents of transuranic waste were repackaged to meet offsite waste acceptance criteria.

During 2007, there were 1,910 cubic yards of mixed low-level waste treated or disposed at the Mixed Low-Level Waste Treatment and Disposal Facility.

There were two defueled reactor compartments from the U.S. Navy shipped to Trench 94 in the 200-East Area in 2007. The total number of Navy reactor compartments received to date is 117 .

During 2007, approximately 439,300 tons of cleanup waste were disposed at the Environmental Restoration Disposal Facility. Approximately 7.2 million tons of remediation waste have been placed in the Environmental Restoration Disposal Facility from initial operations start-up through 2007. 


\section{HANFORD SITE WASTE SUMMARY, 2007}

\begin{tabular}{|c|c|c|}
\hline Activity & Waste Type & Amount \\
\hline \multirow[t]{2}{*}{ Solid waste generated during onsite cleanup activities } & Solid mixed waste & 259 tons \\
\hline & Radioactive waste & 330 tons \\
\hline \multirow[t]{3}{*}{ Dangerous waste shipped off the Hanford Site } & Containerized waste & 53 tons \\
\hline & Bulk solids & 0 \\
\hline & Bulk liquids & 107 tons \\
\hline $\begin{array}{l}\text { Waste volume pumped from underground single-shell waste storage tanks to double- } \\
\text { shell waste storage tanks }\end{array}$ & Liquid waste & 1.1 million gallons \\
\hline Waste volume in underground single-shell waste storage tanks at the end of 2007 & Liquid waste & 29.8 million gallons \\
\hline Waste volume evaporated at the 242-A Evaporator & Liquid waste & 1.2 million gallons \\
\hline Waste added to underground double-shell waste storage tanks & Liquid waste & 1.6 million gallons \\
\hline Waste volume in underground double-shell waste storage tanks at the end of 2007 & Liquid waste & 27 million gallons \\
\hline $\begin{array}{l}\text { Waste dispositioned and shipped offsite from the Waste Receiving and Processing } \\
\text { Facility }\end{array}$ & Solid waste & 904 cubic yards \\
\hline $\begin{array}{l}\text { Waste treated or directly disposed of at the Mixed Low-Level Waste Treatment and } \\
\text { Disposal Facility }\end{array}$ & Mixed low-level solid waste & 1,910 cubic yards \\
\hline Waste disposed of at the Environmental Restoration Disposal Facility & Solid waste & 439,300 tons \\
\hline Volume of aqueous waste received at the Liquid Effluent Retention Facility & $\begin{array}{l}\text { Wastewater containing low levels of } \\
\text { organic compounds and tritium }\end{array}$ & 10.1 million gallons \\
\hline Volume of liquid effluent treated at the Effluent Treatment Facility & $\begin{array}{l}\text { Wastewater containing toxic metals, } \\
\text { radionuclides, ammonia, and } \\
\text { organic compounds }\end{array}$ & 8.69 million gallons \\
\hline Volume of wastewater treated at the 242-A Evaporator & Liquid waste from single-shell tanks & 2.1 million gallons \\
\hline Volume of effluent disposed of at the 200 Area Treated Effluent Disposal Facility & Uncontaminated liquid waste & 346 million gallons \\
\hline $\begin{array}{l}\text { Volume of wastewater treated and disposed of at the } 300 \text { Area Treated Effluent } \\
\text { Disposal Facility }\end{array}$ & Industrial wastewater & 44.4 million gallons \\
\hline
\end{tabular}

\section{Thirty million gallons}

\section{of waste were \\ stored in single-shell \\ underground waste \\ storage tanks at the \\ end of 2007.}

The Radioactive Mixed Waste Disposal Facility consists of two trenches in the 200-West Area. The first waste layer in the first trench has been completed and covered with sand and gravel. The second waste layer has been started and is approximately half filled. Currently, there are approximately 5,360 cubic yards of waste in the first trench. There are approximately 1,570 cubic yards of waste in the second trench.

The low-level burial grounds consist of eight burial grounds located in the 200-East and 200-West Areas that are used for the disposal of low-level waste and mixed waste (i.e., low-level radioactive waste with a dangerous waste component).

Management of Liquid Waste. Liquid effluent is stored, treated, or disposed in facilities that comply with federal and state regulations and facility permits. 
The Effluent Treatment Facility, located in the 200-East Area, treats liquid effluent to remove toxic metals, radionuclides, and ammonia, and destroy organic compounds. The treated effluent is stored in tanks, sampled and analyzed, and discharged onsite to the State-Approved Land Disposal Site. The volume of wastewater treated and disposed of in 2007 was approximately 8.69 million gallons.

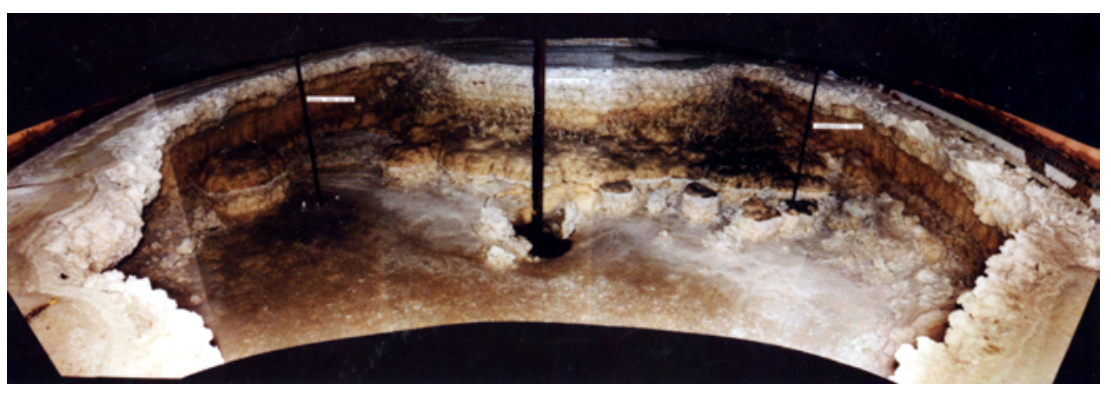

Approximately 10.1 million gallons of liquid waste were stored at the Liquid Effluent Retention Facility at the end of 2007. The volume of wastewater transferred to this facility for storage in 2007 was approximately 15 million gallons.

In 2007, 346 million gallons of uncontaminated effluent were disposed at the 200 Area Treated Effluent Disposal Facility. This facility consists of buried pipelines, three pumping stations, and two 5-acre ponds located east of the 200-East Area. The major source of this effluent was uncontaminated cooling water and steam condensate from the 242-A Evaporator.

Industrial wastewater generated throughout the Hanford Site is collected and treated in the 300 Area Treated Effluent Disposal Facility. The wastewater consists of cooling water, steam condensate, and other industrial wastewater. The volume of industrial wastewater treated and disposed of during 2007 was 44.4 million gallons.

The 242-A Evaporator in the 200-East Area concentrates diluted liquid waste from single-shell underground waste storage tanks, by evaporation. This reduces the volume of liquid waste sent to the

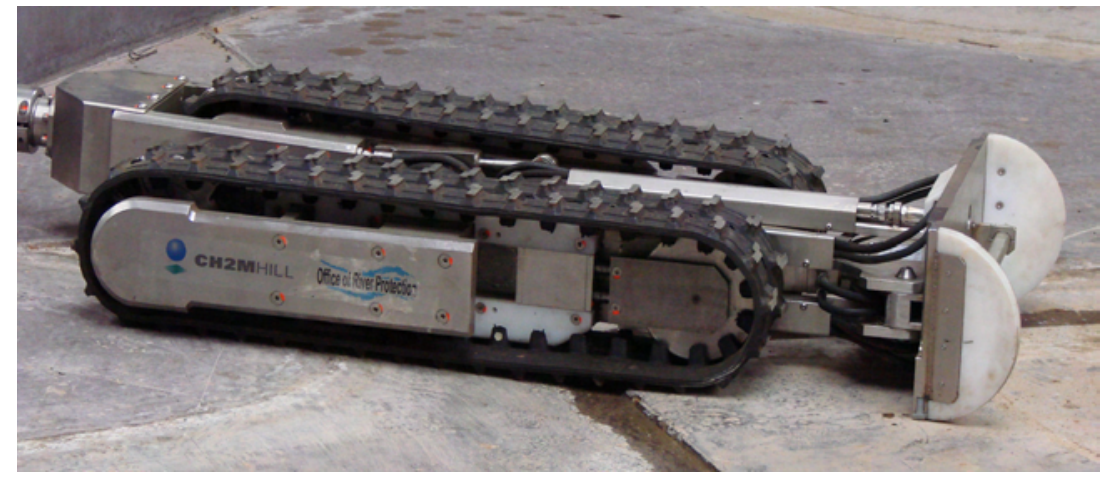
double-shell tanks for storage and reduces the potential need for more doubleshell tanks. The 242-A Evaporator completed two waste campaigns in 2007. The volume of waste treated was 2.1 million gallons, reducing the waste volume by 1.2 million gallons, or approximately $58 \%$ of the total volume. The

The FoldTrack, an in-tank tracked vehicle with a high-pressure spray wand and blade for pushing tank waste, was tested during 2007 and is scheduled for use in actual tanks during 2008. volume of process condensate transferred to the Liquid Effluent Retention Facility for subsequent treatment in the Effluent Treatment Facility was 1.6 million gallons.

Underground Waste Storage Tanks. During 2007, 1.1 million gallons of waste were pumped from single-shell tanks to the double-shell tanks, leaving 29.8 million gallons of waste remaining in the single-shell tanks. At the end 


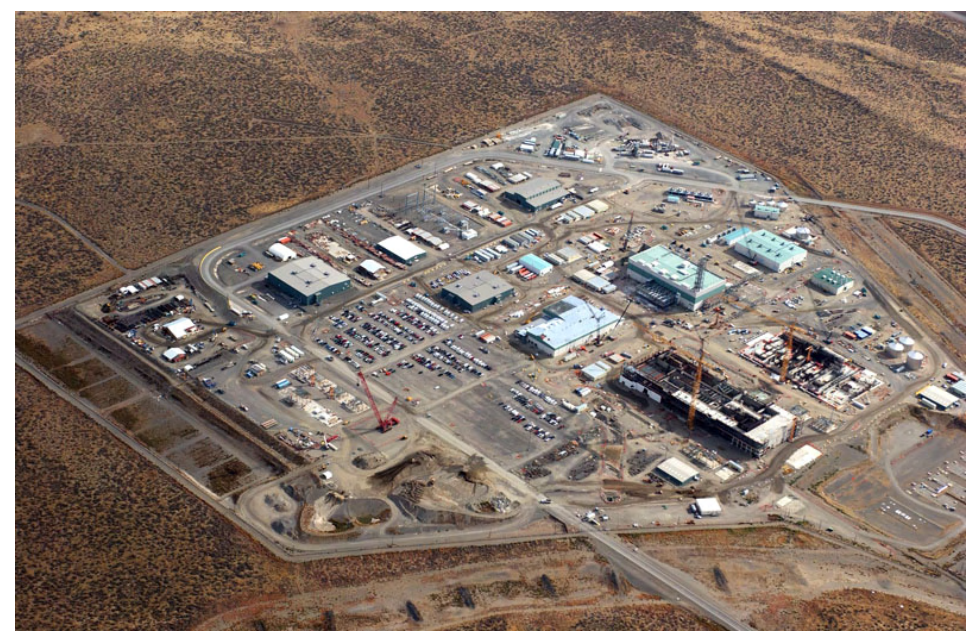

Construction on the Waste Treatment Plant continued during 2007. of 2007, there were 26.8 million gallons of waste in the double-shell tanks.

Hanford Tank Waste Treatment and Immobilization Plant (Waste Treatment Plant). The Hanford Tank Waste Treatment and Immobilization Plant (Waste Treatment Plant) is being built on 65 acres adjacent to the 200-East Area. This plant will treat radioactive and hazardous waste stored in 177 underground tanks. Four major facilities are being constructed: a pretreatment facility, a high-level waste vitrification facility, a low-activity waste vitrification facility, and an analytical laboratory. Supporting facilities are also being constructed.

Construction on these facilities resumed in September 2007, following a delay relating to seismic design criteria.

\section{WASHINGTON STATE INITIATIVE 297: CLEANUP PRIORITY ACT}

Initiative 297, known as the Cleanup Priority Act, was passed by Washington State voters in November 2004. The Cleanup Priority Act sought to add a new chapter to the Mixed Radioactive and Hazardous Waste law and among other things, restricted importing offsite waste to the Hanford Site, established cleanup standards for radioactive releases, and required the DOE to pay a new mixed waste surcharge. In 2006, the federal court ruled the initiative was "invalid in its entirety" because it violated the U.S. Constitution in several areas. Washington State officials appealed the ruling, which was rejected in May 2008.

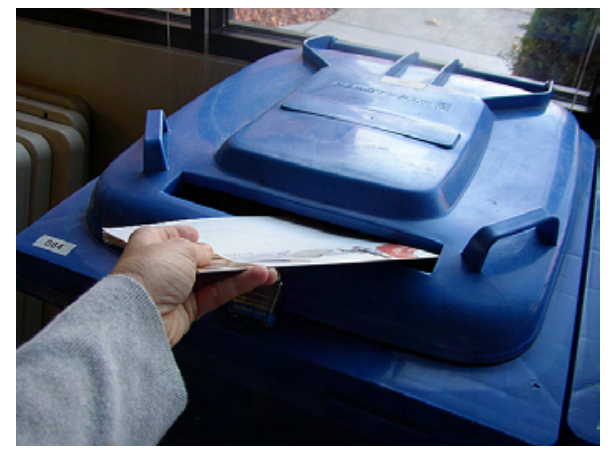

\section{POLLUTION PREVENTION AND WASTE MINIMIZATION}

The Pollution Prevention and Waste Minimization Program is an organized and continuing effort to reduce the quantity and toxicity of hazardous, radioactive, mixed, and sanitary waste generated at the Hanford Site.

Mixed office paper and cardboard were recycled as part of the Pollution Prevention and Waste Minimization Program.
In 2007, 599 metric tons (660 tons) of sanitary and hazardous wastes were recycled through site-wide programs. 


\section{ENVIRONMENTAL AND RESOURCE PROTECTION PROGRAMS}

The White Bluffs are located on the Hanford Site along the eastern shore of the Columbia River in the Wahluke Unit of the Hanford Reach National Monument.

DOE Orders require that emission, effluent, and environmental monitoring programs be conducted at the Hanford Site to verify protection of the site's environmental and cultural resources, the public, and site workers, and to comply with government regulations.

\section{AIR EMISSIONS}

Hanford Site contractors monitor airborne emissions from site facilities to assess the effectiveness of emission treatment and control systems, pollution management practices, and to determine compliance with state and federal regulatory requirements. Small quantities of tritium, strontium-90, iodine129, cesium-137, plutonium-238, plutonium-239/240, plutonium-241, americium-241, and a few other isotopes are released in the 100, 200, 300, 400, and 600 Areas of the Hanford Site.

Non-radioactive air pollutants are emitted from power-generating and chemicalprocessing facilities. These facilities are monitored when activities are known 
Concentrations of

radioactive materials

in air are monitored

continuously on and off

the Hanford Site.

to generate potential pollutants of concern, which include gaseous ammonia, particulate matter, sulfur oxides, nitrogen oxides, volatile organic compounds, carbon monoxide, and lead.

\section{AMBIENT-AIR MONITORING}

Radioactive constituents in air are monitored on the Hanford Site near facilities and operations, at site-wide locations away from facilities, and offsite around the perimeter of the site and in nearby and distant communities.

Ambient-Air Monitoring Near Facilities and Operations. In 2007, ambient air was monitored at 85 locations on the Hanford Site near facilities and operations. Samplers were located primarily at or within approximately 1,640 feet of sites or facilities having the potential for, or a history of, environmental releases. Samples collected from locations at or directly adjacent to Hanford Site facilities had higher radionuclide concentrations than did samples collected farther away. In general, radionuclide concentrations in most Hanford Site near-facility samples were greater than levels measured in samples collected offsite. However, radionuclide concentrations in samples collected in 2007 were at or near background levels and much less than EPA limits.

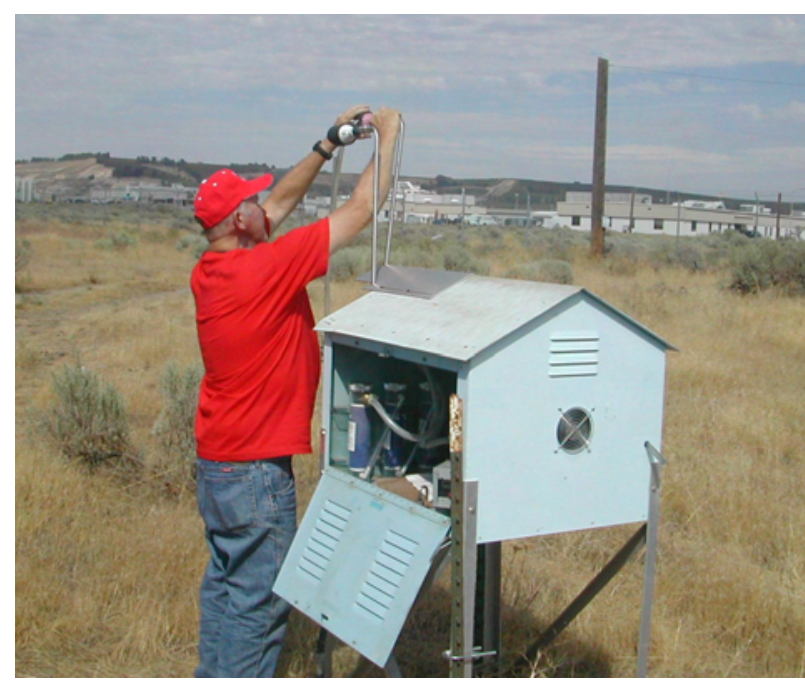

Air samplers on the site were located primarily around major operational areas to maximize the ability to detect radiological contaminants resulting from site operations.
Ambient-Air Monitoring at Site-Wide and Offsite Locations. During 2007, samples were collected at 42 continuously operating site-wide and offsite locations: 23 onsite (site-wide), 11 at site perimeter locations, 7 in nearby communities, and 1 in a distant community. Airborne particle samples were collected at each station biweekly and monitored for gross alpha and gross beta concentrations. Biweekly samples were combined into quarterly composite samples and analyzed for gamma-emitting radionuclides. At 20 locations, samples of atmospheric water vapor were collected every four weeks and analyzed for tritium. All sample results showed very low radiological concentrations in 2007. All radionuclide concentrations in air samples collected in 2007 were low enough to be below the Clean Air Act dose standard of 10 millirem per year.

\section{LIQUID EFFLUENT MONITORING}

Liquid effluent streams from Hanford Site facilities are sampled for gross alpha and gross beta concentrations, as well as for concentrations of selected 
radionuclides. In 2007, only facilities in the 200 Areas discharged radioactive liquid effluent to the ground at a single location, the State-Approved Land Disposal Site. Non-radioactive hazardous materials in liquid effluent are monitored in the 100, 200, 300, and 400 Areas. The effluent is discharged to the State-Approved Land Disposal Site and to the Columbia River. Effluent entering the environment at designated discharge points is sampled and analyzed to determine compliance with applicable Hanford Site discharge permits.

\section{SURFACE-WATER AND SEDIMENT MONITORING}

Samples of surface water and sediment on and near the Hanford Site were collected and analyzed to determine the concentrations of radiological and chemical contaminants from the Hanford Site. Surface water bodies included the Columbia River, onsite ponds, and offsite irrigation sources. Aquatic sediment was collected from the Columbia River and one onsite pond.

Water from the Columbia River. During 2007, Columbia River water samples were collected with automated samplers at fixed-location monitoring stations at Priest Rapids Dam and at the city of Richland, Washington, and analyzed for radionuclides, and from cross-river transects and near-shore locations near the Vernita Bridge, 100-N Area, Hanford town site, 300 Area, and the city of Richland and analyzed for both radionuclides and chemicals. Radiological constituents of interest included gamma-emitting radionuclides, tritium, strontium-90, technetium-99, uranium-234, uranium-235, uranium-238, plutonium-238, and plutonium-239/240. Gross beta and gross alpha concentrations were also monitored. Chemicals of interest included metals and anions. All radiological contaminant concentrations measured in Columbia River water at the fixed sampling locations during 2007 were less than $1 / 25$ th of the DOE effective dose equivalent standard of 100 -millirem per year. Tritium, strontium-90, uranium-234, and uranium-238 were consistently measured

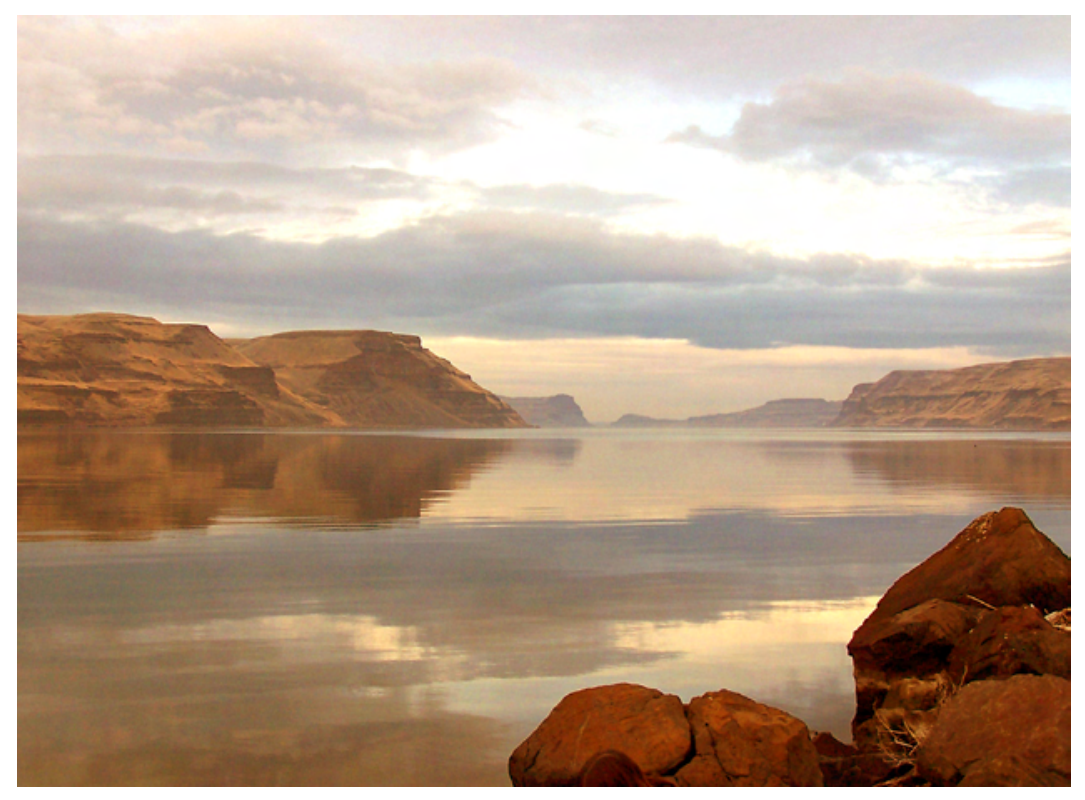

The Columbia River flows through the northern portion of the Hanford Site and forms part of the site's eastern boundary. 


\section{HANFORD SITE MONITORING RESULTS FOR 2007}

\section{What Was Monitored?}

Air

Radioactive and non-radioactive emissions were monitored at Hanford Site facilities. Air particles and gases were monitored for radioactivity onsite near facilities and offsite. Air samples were collected at 85 locations near Hanford Site facilities, at 23 locations around the Hanford Site away from facilities, at 11 site perimeter locations, and at 8 community locations.

Columbia River Water and Sediment

Columbia River Shoreline Spring Water and Sediment

Food and Farm Products

Samples of alfalfa, grapes, milk, potatoes, tomatoes, and wine were collected from locations upwind and downwind of the Hanford Site.

Fish and Wildlife

Game animals and other animals of interest on the Hanford Site and fish from the Hanford Reach of the Columbia River were monitored. Carcass, liver, and muscle samples were analyzed to evaluate radionuclide and metals concentrations. Populations of selected fish and wildlife species were also surveyed or monitored.

Soil Seventy routine soil samples were collected onsite near facilities and operations in 2007 to verify known radiological conditions. There were also soil samples collected to investigate potential contamination at non-routine sampling locations in 2007.

Vegetation
Samples of perennial vegetation were collected near Hanford Site facilities and operations in 2007 and analyzed for radiological contaminants.

\section{The Bottom Line}

All measurements of radioactive materials in air were below recommended guidelines. In general, radionuclide concentrations near facilities were at or near Hanford Site background levels, and were much less than DOE-derived concentration guides. Some Hanford Site values were greater than concentrations measured offsite. The data also show that concentrations of certain radionuclides were higher and widely variable within different onsite operational areas.

As in past years, small amounts of radioactive materials were detected downriver from the Hanford Site. However the amounts were far below federal and state limits. During 2007, there was no indication of any deterioration of Columbia River water or sediment quality resulting from operations at the Hanford Site.

Measurements of radiological contaminants in samples collected at the shoreline springs were less than applicable concentration guides. Most of the 2007 chemical sample results were similar to those reported previously. Concentrations of volatile organic compounds were near or below their detection limits in all samples except one trichloroethene sample. Trace amounts of chlorinated organic compounds were observed at some locations. Concentrations of most metals were below Washington State ambient surface-water chronic toxicity levels.

Radionuclide concentrations measured in sediment samples were similar to concentrations measured in Columbia River sediment, with the exception of the 300 Area where uranium concentrations were above the background concentration measured in the sediments from the reservoir behind Priest Rapids Dam. Metals concentrations in all samples were also similar to concentrations measured in Columbia River sediment samples.

Radionuclide concentrations in samples of food and farm products were at normal environmental levels.

Samples of whitefish, goose, and rabbit were collected and analyzed. Radionuclide levels in wildlife samples were well below levels that are estimated to cause adverse health effects to animals or to the people who may consume them. Concentrations of 16 trace metals were similar to concentrations measured in samples from background locations.

In general, radionuclide concentrations in routine samples collected from or adjacent to waste-disposal facilities in 2007 were higher than concentrations measured in distant communities in 2004 . There were 17 instances of radiological contamination in soil samples investigated in 2007. Of the 17, 13 were cleaned up. The contamination levels at the other locations did not exceed the radiological control limits for the sites and the soil was left in place.

Concentrations of radionuclides were elevated in vegetation samples collected near facilities and operations when compared to concentrations in samples from distant communities collected in 2004. 
in transect and near-shore samples but all measured concentrations were less than applicable Washington State ambient surface-water quality criteria. Metals and anions were detected in Columbia River transect water samples both upstream and downstream of the Hanford Site. All concentrations measured in 2007 were below regulatory limits.

Sediment from the Columbia River. During 2007, samples of the surface layer of Columbia River sediment were collected from six locations that were permanently submerged. Samples were collected from the Priest Rapids Dam, McNary Dam, and Ice Harbor Dam reservoirs, slack water areas along the Hanford Reach, and at the city of Richland. Radionuclides consistently detected at low levels in Columbia River sediment in 2007 included potassium-40, strontium-90, cesium-137, uranium-234, uranium-235, uranium-238, plutonium-238, and plutonium-239/240. Detectable amounts of most metals were found in all river sediment samples. There are no Washington State freshwater sediment quality criteria for comparison to the measured metals values.

Water and Sediment from Ponds. Two onsite ponds, West Lake and the Fast Flux Test Facility pond, were sampled in 2007. Samples were obtained quarterly and included water from both ponds and sediment from West Lake. All water samples

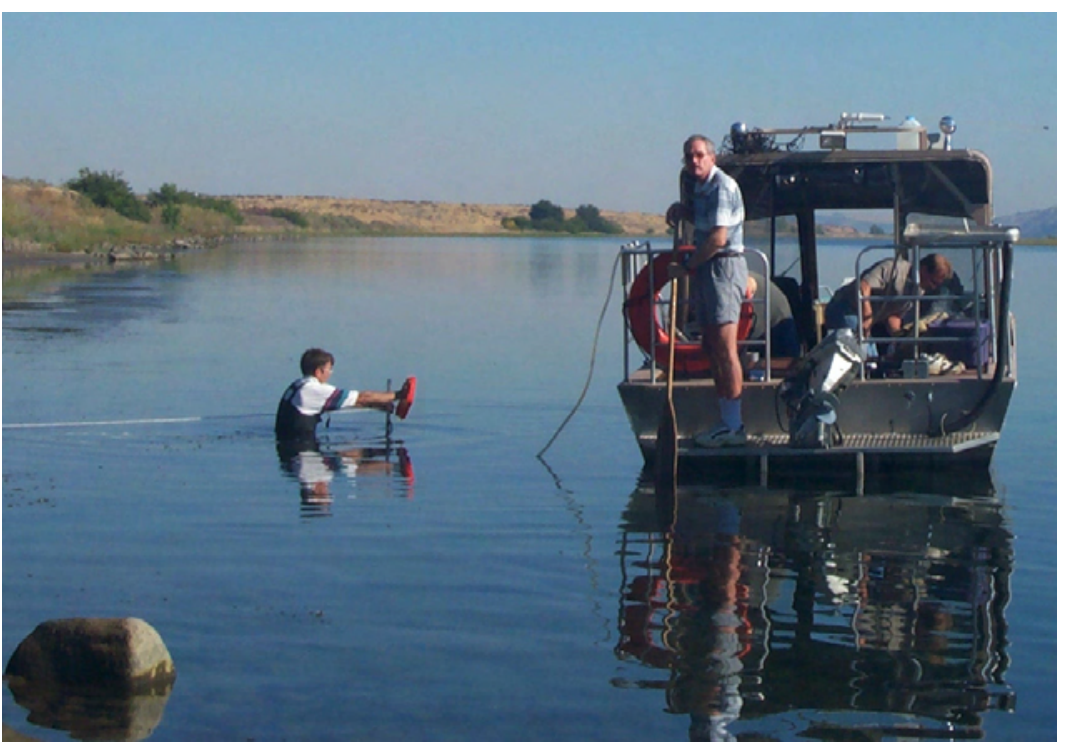
were analyzed for tritium and samples from the Fast Flux Test Facility pond were also analyzed for gross alpha, gross beta, and gamma-emitting radionuclides. All radionuclide concentrations in onsite pond water samples were less than applicable DOE-derived concentration guides and Washington State ambient surface water quality criteria. Concentrations in sediment samples were similar to concentrations measured in prior years.

Offsite Irrigation Water. In 2007, samples were collected from an irrigation water canal in the Riverview area of Pasco and from an irrigation water supply in Benton County near the southern boundary of the Hanford Site. All radionuclide concentrations were at the same levels detected in Columbia River water obtained upstream of the Hanford Site and were below applicable DOE-derived concentration guides and Washington State ambient surfacewater quality criteria. 


\section{COLUMBIA RIVER SHORELINE SPRINGS MONITORING}

Samples of Columbia River shoreline spring water and sediment were collected along the Hanford Reach and analyzed for Hanford-associated radiological and chemical contaminants that are present in groundwater beneath the Hanford Site.

Water from Columbia River Shoreline Springs. Grab samples of spring water were obtained from numerous locations in the fall when Columbia River flows were low. Most samples were analyzed for gamma-emitting radionuclides, gross alpha, gross beta, and tritium. Samples from selected shoreline springs were analyzed for strontium-90, technetium-99, uranium-234, uranium-235, and uranium-238. Most samples were also analyzed

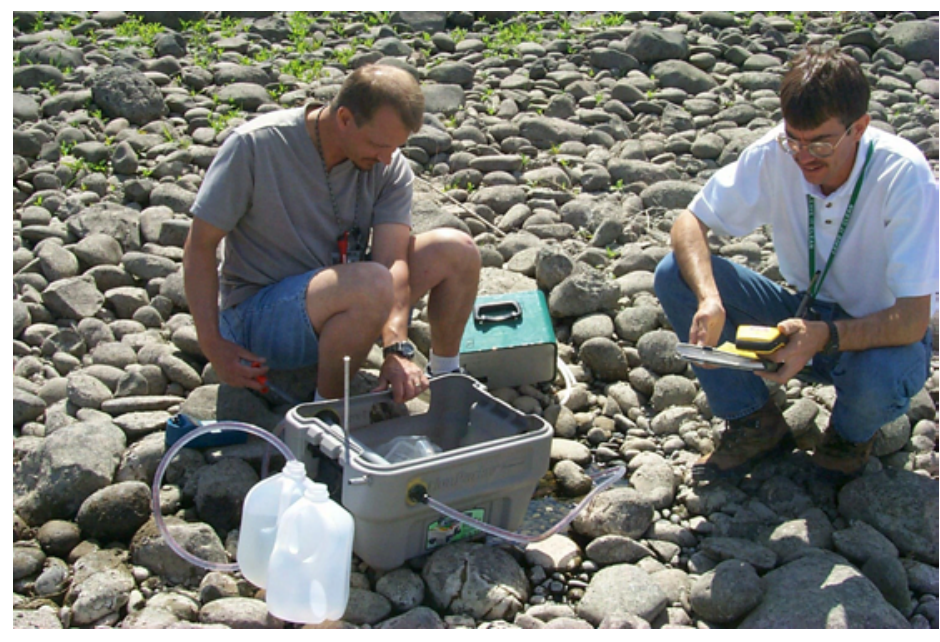

Routine monitoring of shoreline springs helps to characterize the quality of groundwater discharging to the Columbia River and to assess the potential human and ecological risk associated with the spring water. for metals and anions. Samples from some locations were monitored for volatile organic compounds. All radiological contaminants measured in shoreline springs during 2007 were less than the applicable DOE concentration guides.

For most locations in 2007, concentrations of volatile organic compounds were near or below their detection limits in all except one trichloroethene sample. Trace amounts of chlorinated organic compounds were observed at some locations. The concentrations of most metals measured in spring water samples in 2007 were below Washington State ambient surface-water chronic toxicity levels. However, maximum concentrations of dissolved chromium in water at some locations were above the Washington State ambient surface water chronic and acute toxicity levels. Concentrations of arsenic in all samples were below the Washington State ambient surface water chronic toxicity level, but exceeded the EPA limit for the protection of human health for the consumption of water and organisms.

Sediment from Columbia River Shoreline Springs. Shoreline springs sediment samples were collected in the 100-B, 100-F, 100-H, and 100-K Areas, the 300 Area, and at the Hanford town site. Radionuclide concentrations were similar to concentrations measured in Columbia River sediment, with the exception of uranium concentrations in the 300 Area, which were above the concentration measured in sediment from the reservoir behind Priest Rapids Dam, upriver from the Hanford Site. Metals concentrations in all samples were similar to concentrations measured in Columbia River sediment samples. 


\section{RADIOLOGICAL MONITORING OF HANFORD SITE DRINKING WATER}

Samples of treated drinking water were collected monthly at facilities in the $100-\mathrm{K}, 100-\mathrm{N}, 200-$ West, and 400 Areas. Water used in the 400 Area is pumped from wells. Water treated at the other locations is obtained from the Columbia River. Water samples were analyzed for gross alpha, gross beta, tritium, and strontium-90. During 2007, annual average concentrations of all monitored radionuclides in Hanford Site drinking water were below federal and state maximum allowable contaminant levels.

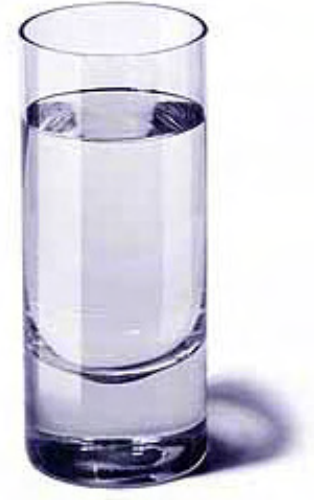

Drinking water is sampled at various locations on the Hanford Site.

\section{GROUNDWATER MONITORING}

At the Hanford Site, liquid waste released to the ground during many years of nuclear materials production has reached groundwater. Hazardous chemicals in the groundwater include carbon tetrachloride, chromium, and nitrate. Radioactive contaminants include strontium-90, technetium-99, iodine-129, tritium, and uranium. Currently, groundwater contaminant levels are greater than drinking water standards beneath $12 \%$ (71.8-square miles) of the area of the Hanford Site. This is down from 17.5\% just a few years ago. The decrease is largely from radioactive decay of some contaminants and contaminant dispersion. Site groundwater does not significantly affect offsite drink-

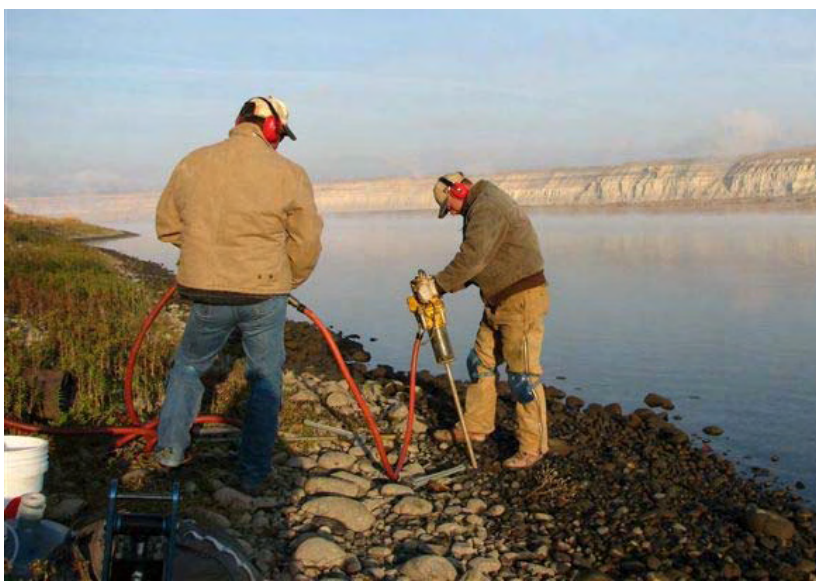

Groundwater is monitored using aquifer tubes at numerous locations along the Hanford Reach of the Columbia River. are possible near-shore effects where Hanford Site groundwater flows into the Columbia River.

\section{FOOD AND FARM PRODUCTS MONITORING}

During 2007, food and farm products including alfalfa, grapes, milk, potatoes, tomatoes, and wines, were collected at places around the Hanford Site and analyzed for radiological contaminants. The concentrations of most radionuclides in food and farm product samples in 2007 were below levels that could be detected by the analytical laboratories. However, tritium and uranium-234 were detected in low levels in some samples, as was naturally occurring potassium- 40 .

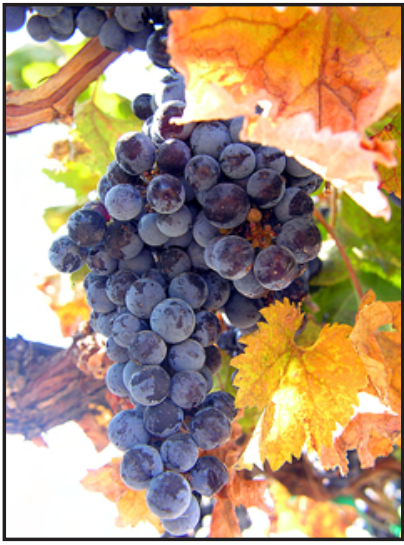

Grapes were collected in the fall and analyzed for radiological contaminants. 


\section{SOIL MONITORING}

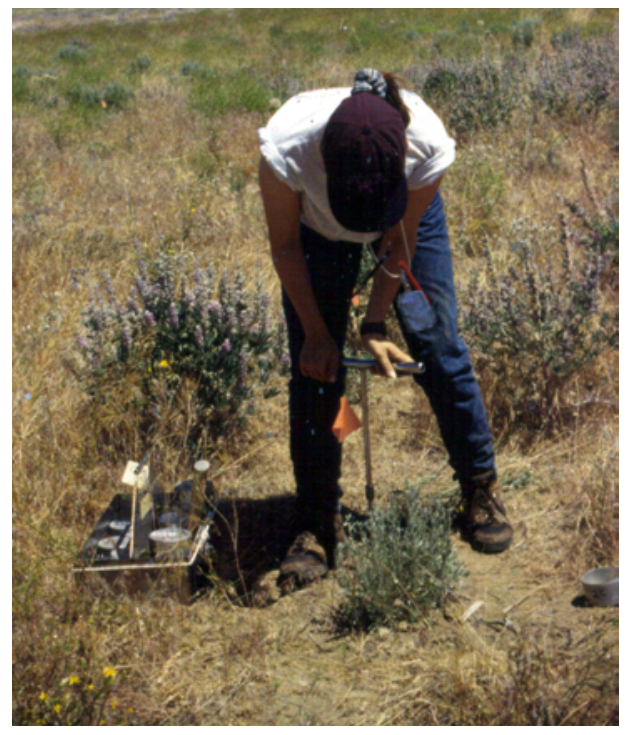

Soil samples were collected near wastedisposal sites and from locations near and downwind of operating facilities and remediation sites.
In 2007, soil samples were collected near facilities and operations at the Hanford Site to evaluate long-term trends in the environmental accumulation of radioactive materials, to detect the potential migration of contaminants, and to monitor the deposition of facility emissions. Samples were analyzed for radionuclides expected to occur in the areas sampled. In general, radionuclide concentrations in soil samples collected from or adjacent to waste-disposal facilities in 2007 were higher than the concentrations in samples collected farther away, and were higher than concentrations measured offsite in previous years. The data also showed that concentrations of certain radionuclides in 2007 were higher within different operational areas when compared to concentrations measured in distant communities in previous years. Generally, the predominant radionuclides detected were activation and fission products in the $100-\mathrm{N}$ Area, fission products in the 200 and 600 Areas, and uranium in the 300 and 400 Areas.

\section{VEGETATION MONITORING}

Plant populations are routinely surveyed on the Hanford Site, including rare or protected plant species, contaminant monitoring of perennial vegetation growing near facilities and work areas on the site, and control of contaminated or unwanted vegetation on the site.

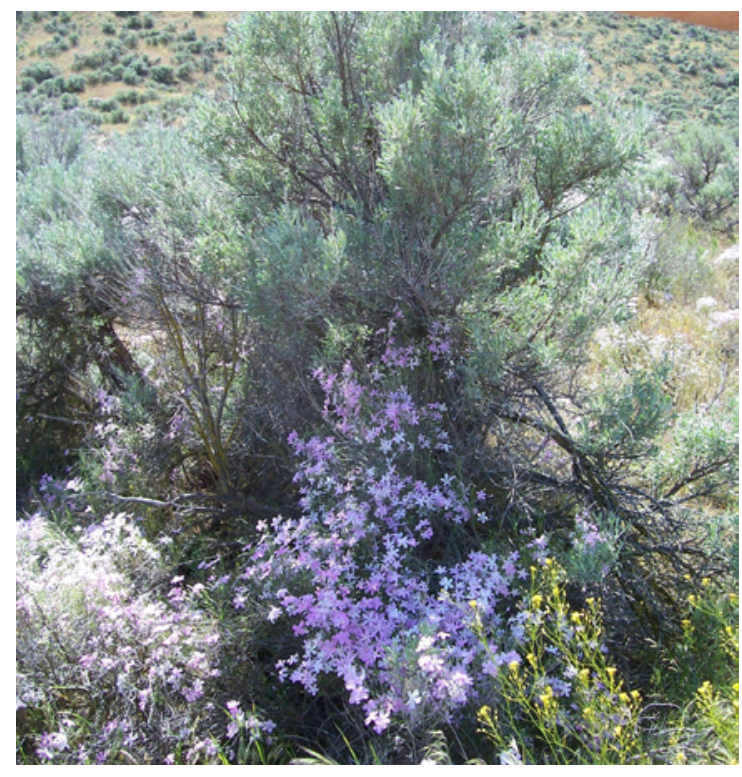

Phlox, shown growing adjacent to sagebrush, is a spring perennial that is abundant on the Hanford Site.
Plant Communities and Population Surveys. Plant populations monitored on the Hanford Site include species listed by Washington State as endangered, threatened, or sensitive, and species listed as review group 1. Monitoring data are used to develop baseline information and to monitor for changes resulting from Hanford Site operations. Surveys for rare annual species were conducted in 2007 as part of annual compliance review activities for firebreak construction and maintenance.

\section{Vegetation Monitoring Near Hanford Site Facilities and Oper-}

ations. Vegetation samples were collected on or adjacent to former waste-disposal sites, and from locations downwind and near or within the boundaries of operating facilities and remedial action sites to monitor for radioactive contaminants. In general, radionuclide concentrations in vegetation samples collected from, or adjacent to, waste-disposal facilities in 2007 were higher than concentrations in samples collected farther away and were significantly higher than concentrations measured offsite in prior years. 
Generally, the predominant radionuclides detected were activation and fission products in the 100-N Area, fission products in the 200 and 600 Areas, and uranium in the 300 and 400 Areas.

Investigations of Radioactivity in Vegetation Near Hanford Site Facilities and Operations. During 2007, radiological contamination was found in 62 vegetation samples collected around areas of known or suspected contamination or around specific project sites. All of the samples were tumbleweeds or tumbleweed fragments. All were field surveyed for gross alpha and gross beta, but none were analyzed for specific radionuclides. All were disposed in onsite burial grounds.

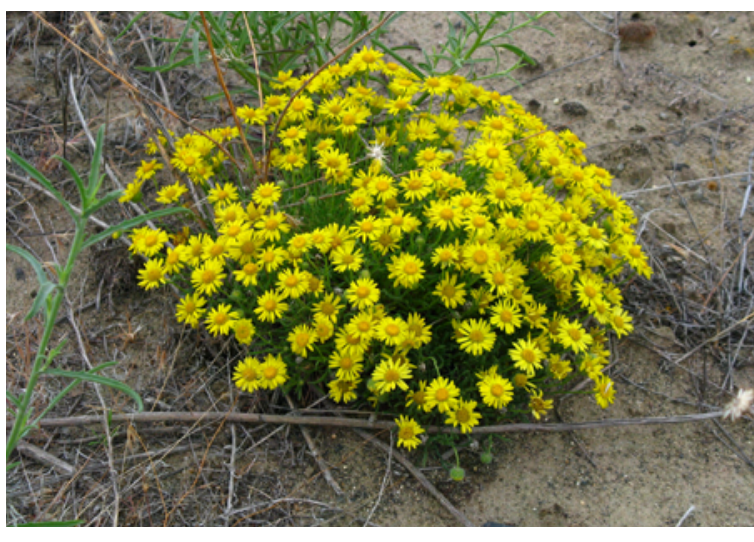

Vegetation Control Activities. Vegetation control at the Hanford Site consists Piper's daisy, a Washington State sensitive species, is found on the Hanford Site.

of cleaning up contaminated plants that can be a threat to workers or the public, controlling or preventing the growth or re-growth of plants in contaminated or potentially contaminated areas on the site, and monitoring and removing 10 high-priority noxious plant species.

\section{FISH AND WILDLIFE MONITORING}

Fish and wildlife monitoring on the Hanford Site includes surveying and monitoring Hanford Site animal populations, monitoring fish and wildlife tissues for contaminants from the site, and managing wildlife that might affect workers or have become radiologically contaminated.

Wildlife Populations Surveys. Four fish and wildlife species on the Hanford Site are surveyed annually: fall Chinook salmon, steelhead, bald eagles, and mule deer. The number of fall Chinook salmon spawning nests (redds) in the Hanford Reach is estimated by aerial surveys. The peak redd count in the fall of 2007 was estimated at 4,018, lower than the 2006 count of 6,190 and below the previous 5 -year average of 8,011. Two aerial surveys were conducted to identify possible steelhead spawning areas; none were found.

A pair of adult bald eagles returned during 2007 to occupy the historical nest site in the vicinity of the former White Bluffs town site; however, the nest was abandoned for unknown reasons.

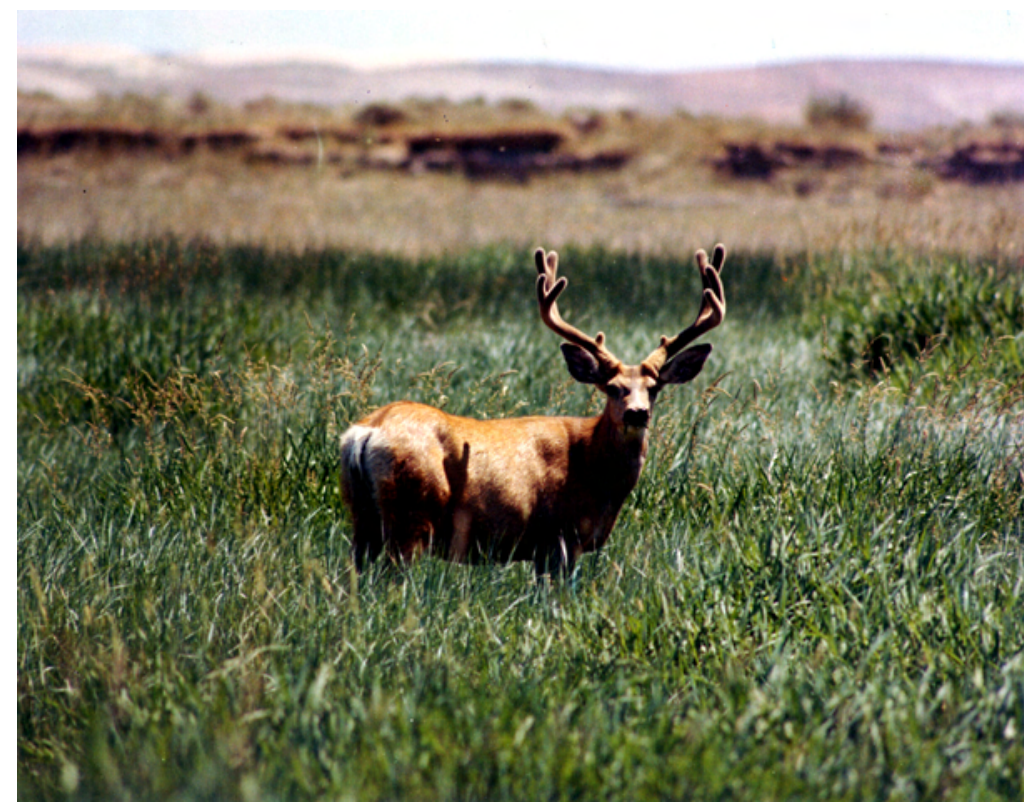

Mule deer are surveyed annually on the Hanford Site. 


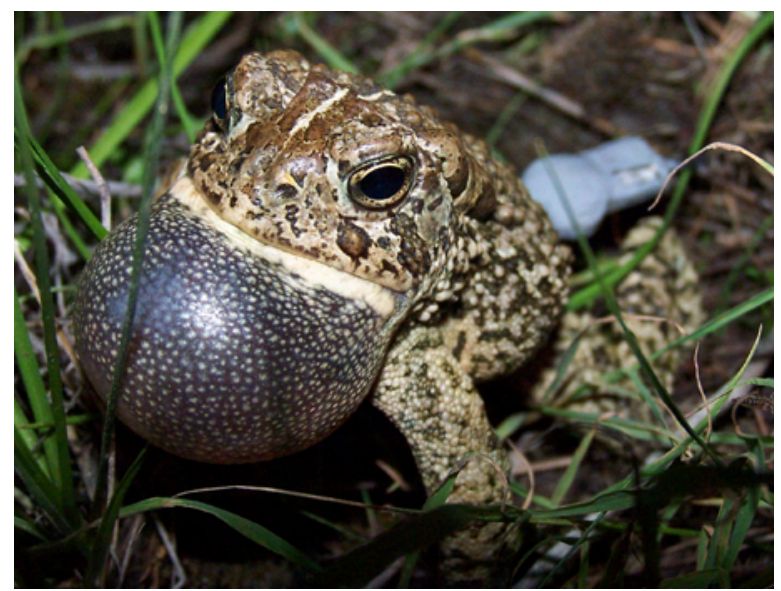

Woodhouse's toads are found along the Columbia River and have adapted to both aquatic and terrestrial habitats.

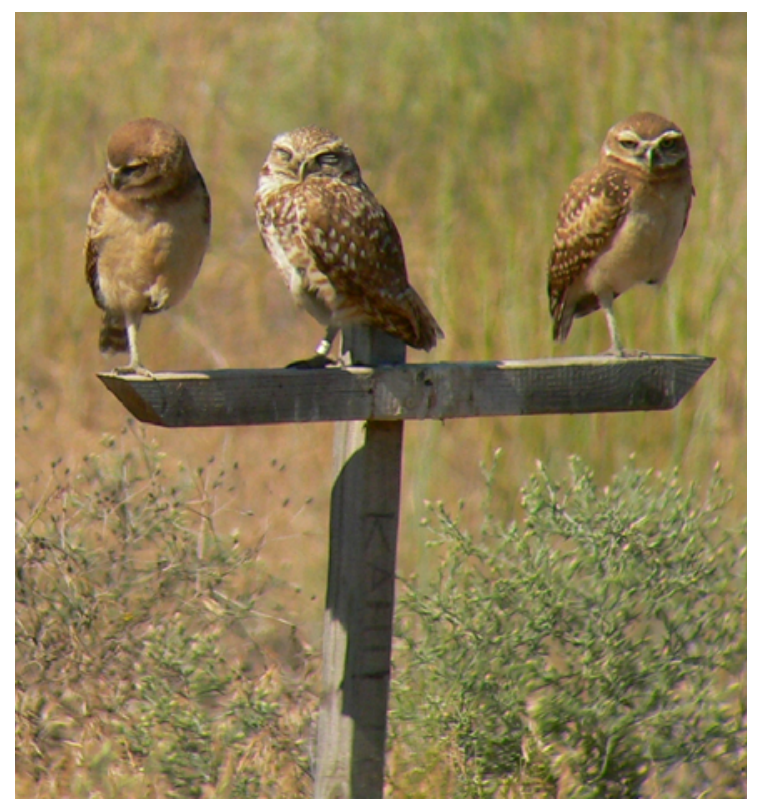

Burrowing owls, a Washington State candidate species and federal species of concern, were monitored on the Hanford Site during 2007.
Roadside surveys were conducted for mule deer on the Hanford Site to assess age and sex ratios and the frequency of testicular atrophy in males. Testicular atrophy has been associated with an unusually large number of older deer residing on the Hanford Site.

Habitat and Species Characterizations. Ecological monitoring on the Hanford Site includes the characterization of breeding locations, habitat use, and distribution of key wildlife species. In 2007, characterization studies focused on the Woodhouse's toad and the burrowing owl, a Washington state candidate species and federal species of concern in this region. Toad habitat distributions were monitored using radio telemetry and burrowing owl distribution and nesting habitat were examined.

Monitoring Fish and Wildlife for Hanford-Produced Contaminants. In 2007, Canada geese, cottontail rabbits, and whitefish were collected at locations on and around the Hanford Site. Tissue samples were analyzed for strontium-90 and gamma emitters, including cesium-137. Since the 1990s, strontium-90 and cesium-137 have been the most frequently measured radionuclides in fish and wildlife samples. Cesium-137 was not detected in any sample in 2007. Strontium-90 was found above the analytical detection limit in the whitefish, rabbit, and goose samples collected during 2007. Liver tissues from most organisms were monitored for up to 17 trace metals. Concentrations of trace metals in whitefish samples were elevated for many samples in 2007, with the exception of nickel and selenium in fish collected from 100-N and 100-D Areas that were similar to or less than concentrations collected in previous years. Trace metal concentrations in rabbit samples collected on the Hanford Site in 2007 were not detected or were less than or similar to concentrations from previous years; however, selenium concentrations were elevated compared with background samples from 2005.

Control of Pests and Contaminated Biota. Animals (including insects) must be controlled when they become a nuisance, potential health problem, or are contaminated with radioactivity. Biological control personnel responded to approximately 28,000 animal control requests from Hanford Site employees in 2007. There were 35 contaminated animals or animal-related materials discovered in 2007. 


\section{EXTERNAL RADIATION MONITORING}

In 2007, external radiation at the Hanford Site was monitored onsite in relative close proximity to known, suspected, or potential radiation sources. A thermoluminescent dosimeter system is used to measure external radiation at the Hanford Site. Additionally, radiation surveys were conducted at some locations using portable instruments to monitor and detect contamination, providing a screening for external radiation fields.

Thermoluminescent Dosimeters. During the year, external radiation levels can vary from $15 \%$ to $25 \%$ at any location because of changes in soil moisture and snow cover. With the exception of the 200-West Area, measured radiation levels were similar to or lower than levels measured in 2006.

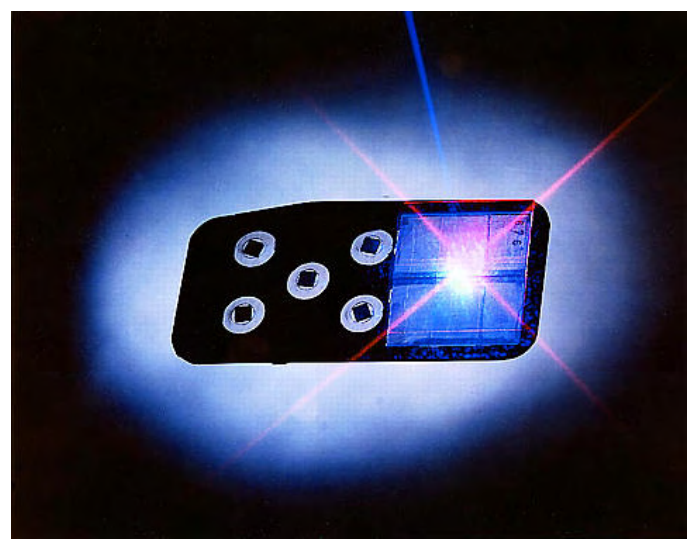

Radiation Surveys. In 2007, 464 radiation surveys were conducted at and

Thermoluminescent dosimeters are used to measure external radiation at the Hanford Site. around active and inactive waste-disposal sites. During 2007, the Hanford Site had approximately 1,464 acres of outdoor contaminated areas of all types and approximately 1,482 acres that contained underground radioactive materials, not including active facilities. No new areas of significant size were discovered during 2007.

All doses from Hanford Site activities in 2007 were much lower than EPA and DOE allowable

\section{POTENTIAL RADIOLOGICAL DOSES FROM 2007 HANFORD SITE OPERATIONS}

During 2007, potential radiological doses to the public and biota from Hanford Site operations were evaluated to determine compliance with pertinent regulations and limits. Doses were assessed in terms of 1) total dose (multiple pathways) to the hypothetical, maximally exposed individual at an offsite location; 2) average dose to the collective population living within 50 miles of Hanford Site operating areas; 3) dose for air pathways using EPA methods; 4) dose to workers on the site consuming drinking water; 5) inhalation doses associated with measured radionuclide concentrations in air; 6) doses from non-DOE industrial sources on and near the Hanford Site; and 7) absorbed dose

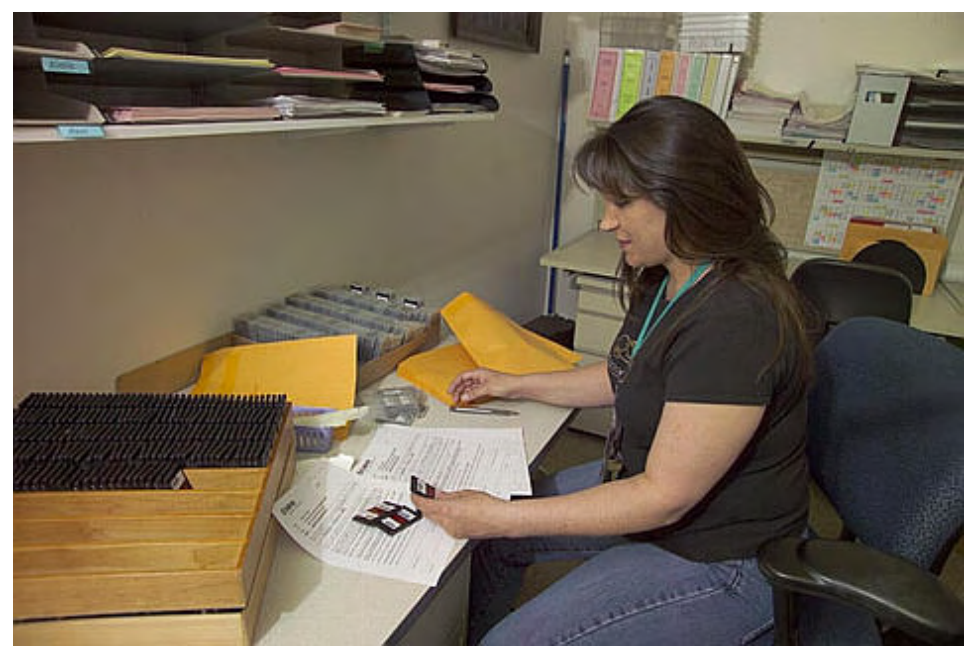

Thermoluminescent dosimeters are collected and processed quarterly. 
received by animals exposed to contaminants released to the Columbia River and in onsite surface water bodies. All doses from Hanford Site activities in 2007 were lower that EPA and DOE standards.

\section{CLIMATE AND METEOROLOGY}

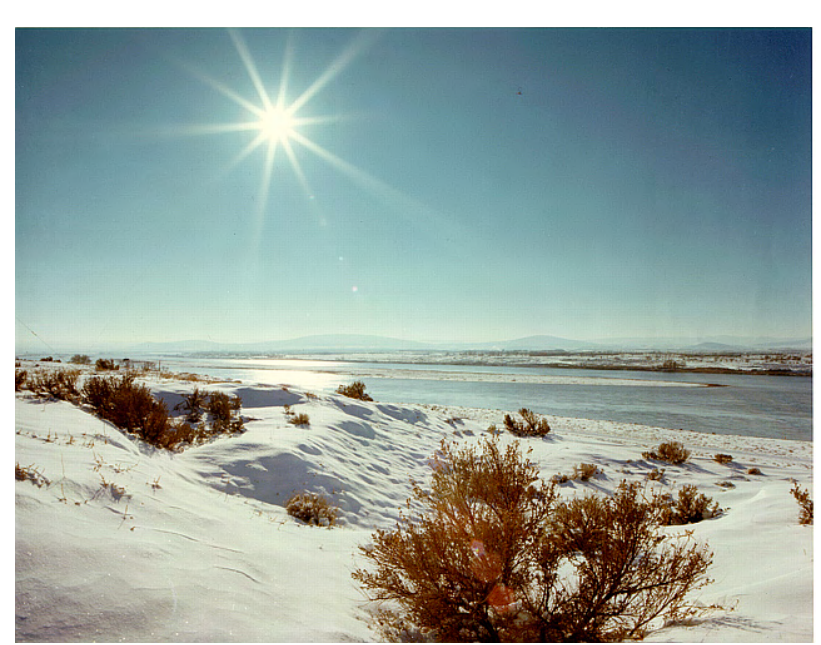

During 2007, snowfall totaled 10 inches on the Hanford Site.

\section{Meteorological}

measurements are

taken to support

Hanford Site emergency

preparedness and

response, site

operations, and

atmospheric dispersion

calculations for dose

assessments. (1945-2007).
Meteorological measurements support Hanford Site emergency preparedness, site operations, and atmospheric dispersion calculations. Activities include weather forecasting and maintaining and distributing climatological data.

The calendar year 2007 average temperature and precipitation totals were below normal. The average temperature for 2007 was $53.5^{\circ} \mathrm{F}$, which was $0.1^{\circ} \mathrm{F}$ below normal $\left(53.6^{\circ} \mathrm{F}\right)$. Four months during 2007 were warmer than normal; seven months were cooler than normal.

Precipitation during 2007 totaled 5.48 inches, which is $79 \%$ of normal (6.98 inches). Snowfall for 2007 totaled 10 inches, compared to normal snowfall of 15.4 inches.

The average wind speed during 2007 was 8.0 miles per hour, which was 0.4 mile per hour above normal. The peak gust for the year was 60 miles per hour on November 12 and December 15.

Two dust storms were recorded at the Hanford Meteorology Station during 2007, less than the 5 per year average for the entire period of record

\section{CULTURAL AND HISTORIC RESOURCES}

DOE is responsible for managing and protecting the Hanford Site's cultural and historic resources. The Hanford Cultural and Historic Resources Program assists DOE in managing cultural and historic resources responsibly and in accordance with applicable regulatory requirements.

Cultural resources reviews are required before a federally funded, federally assisted, or federally licensed ground disturbance or building alteration/ demolition project can occur. Cultural resource reviews identify properties within the proposed project area that may be eligible for, or listed in, the National Register of Historic Places, and evaluate the project's potential to 
affect any such property. During 2007, 129 cultural resource reviews were requested by Hanford Site contractors.

The Hanford Site conducts a monitoring program to assess the effects of weathering and erosion or unauthorized excavation and collection upon the site's cultural resources. Activities include onsite inspections of important sites. In 2007, 34 sites were visited and minor impacts from recreation, natural erosion, and animal activity were documented.

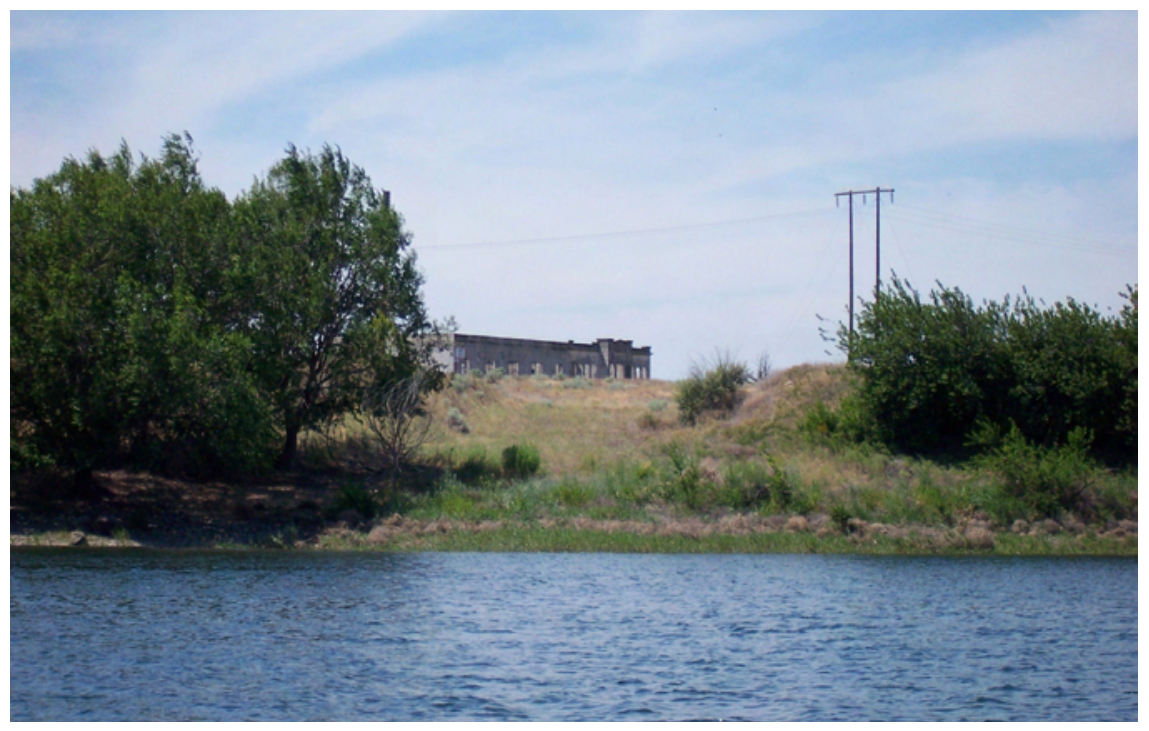

Hanford High School, one of the remaining buildings at the old Hanford town site, is eligible for listing in the National Register of

\section{QUALITY ASSURANCE}

Comprehensive quality assurance programs, which include various quality control practices and methods to verify data, are maintained by monitoring and surveillance projects to assure data quality. The programs are implemented through quality assurance plans designed to meet requirements of the American National Standards Institute/American Society of Mechanical Engineers and DOE Orders. Quality assurance plans are maintained for all activities, and auditors verify conformance.

Samples are collected and analyzed according to documented standard procedures. Analytical data quality was verified by a continuing program of internal laboratory quality control, participation in interlaboratory crosschecks, replicate sampling and analysis, submittal of blind standard samples and blanks, and splitting samples with other laboratories. 


\section{REPORT INQUIRIES}

Inquiries about this booklet or comments and suggestions about its content may be directed to Mr. D.C. (Dana) Ward, U.S. Department of Energy, Richland Operations Office, P.O. Box 550, Richland, Washington 99352 (Dana_C_Ward@rl.gov), or to Ms. J.P. (Joanne) Duncan, K6-85, Pacific Northwest National Laboratory, P.O. Box 999, Richland, Washington 99352 (joanne.duncan@pnl.gov).

Copies of this summary booklet and the 2007 report have been provided to many public libraries in communities around the Hanford Site and to several university libraries in Washington and Oregon. Copies also can be found at the DOE's Public Reading Room located in the Consolidated Information Center, Room 101L, in Richland, Washington. Copies of the 2007 report can be obtained from Ms. J.P. Duncan, K6-85, Pacific Northwest National Laboratory, P.O. Box 999, Richland, Washington 99352 (joanne.duncan@pnl.gov) while supplies last. The reports can also be accessed on the Internet at http://hanford-site.pnl.gov/envreport. 